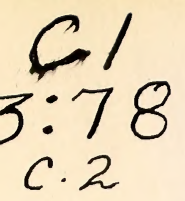

NORTH Carolina

DePartment of Conservation and Development

Division OF Mineral Resources

JASPER L. STUCKEY, State Geologist

BULLETIN NUMBER 78

\title{
Cretaceous Ostracoda From Wells In The Southeastern United States
}

\author{
By \\ Frederick M. Swain and Philip M. Brown \\ University of Minnesota, Minneapolis, Minnesota \\ U. S. Geological Survey, Raleigh, North Carolina
}

PREPARED COOPERATIVELY BY THE GEOLOGICAL SURVEY, UNITED STATES DEPARTMENT OF THE INTERIOR 


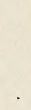




\section{North Carolina}

Department of Conservation and Development

Division of Mineral Resources

JASPER L. Stuckey, State Geologist

BULleTiN NUMBER 78

\section{Cretaceous Ostracoda From Wells In The Southeastern United States}

By

Frederick M. Swain and Philip M. Brown

University of Minnesota, Minneapolis, Minnesota

U. S. Geological Survey, Raleigh, North Carolina

PREPARED COOPERATIVELY BY THE GEOLOGICAL SURVEY, UNITED STATES DEPARTMENT OF THE INTERIOR 


\section{MEMBERS OF THE BOARD OF CONSERVATION AND DEVELOPMENT}

HARgrove Bowles, JR., Chairman

Greensboro

John M. Akers Gastonia

Dr. Mott P. Blair Siler City

Hargrove Bowles, Jr.

Greensboro

Robert E. Bryan

Goldsboro

Mrs. B. F. Bullard Raleigh

Daniel D. Cameron

Wilmington

Mrs. Fred Y. Campbell

Waynesville

Dr. John Dees

Burgaw

William P. Elliott, Sr.

Marion

E. Harvey Evans, Jr.

Laurinburg

E. R. Evans

Ahoskie

Andrew Gennett

Asheville

Luther Warren Gurkin, Jr.

Plymouth

Woody R. Hampton Sylva

Charles Hayworth High Point

Gordon C. Hunter Roxboro

Roger P. Kavanagh, Jr.

Greensboro

R. Walker Martin

Lexington

Carl G. McCraw

Charlotte

Lorimer W. Midgett

Elizabeth City

Ernest E. Parker, Jr.

Southport

R. A. Pool

Clinton

Eric W. Rodgers

Scotland Neck

Robert W. Scott

Haw River

James A. Singleton

Red Springs

J. Bernard Stein

Fayetteville

Paul H. Thompson

Fayetteville

Charles B. Wade, Jr.

Winston-Salem 
Raleigh, North Carolina

March 20, 1964

To His Excellency Honorable Terry Sanford Governor of North Carolina

Sir:

I have the honor to submit herewith manuscript for publication as Bulletin 78, "Cretaceous Ostracoda from Wells in the Southeastern United States," by Frederick M. Swain and Philip M. Brown.

This report contains information on the subsurface geology of northeastern North Carolina that should be of value to those interested in the potential mineral resources of that part of the State.

Respectfully submitted,

Robert L. Stallings, Jr. Director 
Abstract

Introduction _-... 1

Acknowledgments $\quad 1$

Lower Cretaceous Ostracoda from wells in central and northeastern North Carolina

Ostracoda from the Atkinson Formation _ 5

Trinity Ostracoda described by Vanderpool $\quad 8$

Systematic descriptions of Ostracoda $\quad 8$

Cytherellidae $\quad 8$

Cytherella $\quad 8$

Cytherelloidea 12

Bairdiidae $\quad 12$

Bairdia 12

Paracyprididae $\quad 13$

Paracypris 13

Ilyocyprididae

Cypridea $\quad 15$

Cytherideidae $\quad 17$

Paracyprideis (?) $\quad 17$

Fossocytheridea 17

Haplocytheridea ___ 21

Clithrocytheridea $\quad 22$

Dolocytheridea

Perissocytheridea

Schuleridea $\quad 23$

Asciocythere $\quad 26$

Eucythere $\quad 27$

Eucytheroides $\quad 28$

Brachycytheridae

Brachycythere $\quad 28$

Alatacythere $\quad 29$

Trachyleberidae _.......... 29

Cythereis $\quad 30$

Cytheruridae $\quad 35$

Eocytheropteron $\quad 35$

Orthonotacythere $\quad 40$

Loxoconchidae 41

Loxoconcha $\quad 41$

References

TABLE 1. Correlation of strata in North Carolina wells 2

2. Occurrence of Ostracoda in North Carolina wells discussed in this report

3. Occurrence of Ostracoda in Alabama, Florida, and Georgia wells 


\section{ILLUSTRATIONS}

Page

PLATES 1-5

FIGURE 1. Index map showing location of wells in North Carolina

2. Index map showing location of wells in Alabama, Florida, and Georgia

3. Cytherella beyrichoides Swain and Brown, n. sp. $\quad 10$

Cypridea diminuta Vanderpool $\quad 10$

Cypridea dequeenensis Swain and Brown, n. sp. $\quad 10$

4. Cypridea dequeenensis Swain and Brown, n. sp. 10

Cypridea wyomingensis Jones _ 10

5. Fossocytheridea lenoirensis Swain and Brown, n. gen., n. sp. 18

6. Clithrocytheridea halifaxensis Swain and Brown, n. sp. 18

Perissocytheridea odomensis Swain and Brown, n. sp. $\quad 18$

Schuleridea washitaensis (Alexander) 18

7. Asciocythere rotunda (Vanderpool) 24

Asciocythere perforata (Vanderpool) _ 24

8. Eucytheroides pustulosa (Swain) _ 24

Eucythere semiglypta Swain and Brown, n. sp.

9. Cythereis eaglefordensis Alexander

10. Cythereis fredricksburgoides Swain and Brown, n. sp. 34 Cythereis praeornata Swain and Brown, n sp. 34

11. Eocytheropteron venoides Swain and Brown, n. sp. 36

Eocytheropteron greenvillensis Swain and Brown, n. sp. _.. 36

Eocytheropteron trinitiensis Vanderpool … 36 
Digitized by the Internet Archive in 2013

http://archive.org/details/cretaceousostrac1964swai 


\title{
Cretaceous Ostracoda From Wells in the Southeastern United States
}

By

\author{
Frederick M. SWAin and Philip M. Brown \\ University of Minnesota, Minneapolis, Minnesota \\ U. S. Geological Survey, Raleigh, North Carolina
}

\begin{abstract}
Two previously undescribed early Cretaceous ostracode faunas, important in the interpretation of Coastal Plain geology, but of different age and geographic distribution, are treated in this paper. A third early Cretaceous collection, previously described, is here re-described because of its stratigraphic importance.

A marine ostracode fauna of probable Albian age, previously unknown, is described from shallow wells in central and northeastern North Carolina. The assemblage, which includes eleven new species and two new genera, is thought to represent nearshore deposition in a lagoonal environment, characterized in part by brackish water.

Also described is an ostracode fauna from the subsurface Atkinson Formation of southern Alabama, northern Florida, and Georgia. The upper member of the Atkinson Formation, that previously has been correlated with the Eagle Ford of Texas, contains four species, one of which is new. The lower member of the Atkinson Formation, that previously has been correlated with the Woodbine of Texas, contains seventeen species, four of which are new.

Vanderpool's type specimens of Ostracoda from the Lower Cretaceous Trinity Group of northeastern Texas, southern Arkansas, and northern Louisiana have been examined, described, and reillustrated. Several taxonomic changes have been made in the Trinity species.
\end{abstract}

\section{INTRODUCTION}

Three collections of Cretaceous Ostracoda are described and illustrated in this paper. Although the three collections differ in age and in geographic distribution, they contribute to general knowledge of Cretaceous ostracodes of the southeastern United States, and are treated together for this reason. The three collections represent deposits of Trinity age, possible Fredericksburg and Washita age, and Woodbine and Eagle Ford age.

An assemblage of Ostracoda, collected by Brown from cuttings from water wells in central and northeastern North Carolina, represents an apparent nearshore assemblage of Albian age that does not have a recognizable counterpart among previously described Cretaceous ostracode faunas. In addition, it provides new data concerning the areal distribution of marine Cretaceous sediments in the Middle Atlantic States.

Ostracoda from the Atkinson Formation of southern Alabama, northern Florida, and Georgia were submitted to Swain in 1951 by Paul L. and
Esther Applin. Scarcity of information on Ostracoda of this age in the southeastern states, and their relation to the North Carolina material described in this paper, have led to their inclusion here.

The Trinity Ostracoda, described by Vanderpool (1928 and 1933) are in need of reconsideration taxonomically, and are, therefore, redescribed and re-illustrated. These ostracodes were first described by Vanderpool from surface localities in northeastern Texas and southern Arkansas, and recorded from wells in northern Louisiana by Calahan (1939).

\section{Acknowledgments}

Appreciation is expressed to Paul L. and Esther R. Applin for providing the Atkinson specimens, and to A. R. Loeblich, Jr., for arranging the loan of the Vanderpool collection.

Type specimens are deposited in the U. S. National Museum. Museum numbers extend from 132376 through 132532. 


\section{Lower Cretaceous Ostracoda From Wells In Central and Northeastern North Carolina}

An occurrence of previously unknown marine rocks of Early Cretaceous age was reported by Brown (1958) in several water wells in Lenoir and Pitt Counties, North Carolina. Recently, additional wells have penetrated these rocks that contain an abundant ostracode fauna, probably of Albian age.

The Ostracoda of these pre-Tuscaloosa deposits are of interest because they indicate nearshore deposition in a lagoonal environment, characterized in part by brackish water, and differ, therefore, from Cretaceous ostracode faunas previously described from the Atlantic and Gulf coastal areas. A somewhat similar fauna, believed to be much older, was described by Swain (1952) from the Lower Cretaceous section in a well at Cape Hatteras, North Carolina.

The Lower Cretaceous rocks consist of interlayered sandstone, mudstone, and shale that overlie crystalline rock and in turn are overlain by the Tuscaloosa Formation of Late-Cretaceous age. The stratigraphic relationships of the Lower Cretaceous rocks with younger rock units in the area are shown in Table 1.

Three recognizable but intratransitional facies occur in the Lower Cretaceous section from top to bottom as follows:

\begin{tabular}{|c|c|c|c|c|c|c|c|c|c|c|c|}
\hline \multirow{2}{*}{$\begin{array}{c}\text { Well } \\
\text { Number }\end{array}$} & \multirow{2}{*}{$\begin{array}{c}\text { Elevation } \\
\text { of } \\
\text { Well } \\
\text { (feet) }\end{array}$} & \multirow{2}{*}{$\begin{array}{l}\text { Total } \\
\text { Depth }\end{array}$} & \multirow{2}{*}{$\begin{array}{c}\text { Beds of } \\
\text { Post- } \\
\text { Miocene } \\
\text { Age } \\
\text { (feet) }\end{array}$} & \multirow{2}{*}{$\begin{array}{l}\text { Beds of } \\
\text { Miocene } \\
\text { Age } \\
\text { (feet) }\end{array}$} & \multirow{2}{*}{$\begin{array}{c}\text { Navarro } \\
\text { (feet) }\end{array}$} & \multirow{2}{*}{$\frac{\text { Taylor }}{\underset{\text { Equivalen }}{\text { (feet) }}}$} & \multirow{2}{*}{ Austin } & \multirow{2}{*}{$\begin{array}{c}\text { Tuscaloosa } \\
\text { (feet) }\end{array}$} & \multirow{2}{*}{$\begin{array}{c}\text { Beds of } \\
\text { Early } \\
\text { Cretaceous } \\
\text { Age } \\
\text { (feet) } \\
\end{array}$} & \multirow{2}{*}{$\frac{\begin{array}{c}\text { Basement } \\
\text { Depth } \\
\text { (feet) }\end{array}}{\text { Rock Type }}$} & \multirow{2}{*}{$\begin{array}{c}\text { Basis of } \\
\text { Correlation }\end{array}$} \\
\hline & & & & & & & & & & & \\
\hline LE-T6-55 & +53 & 823 & $0-29$ & - & $29-143$ & $143-282$ & $282-566$ & $566-713$ & $824+$ & - & $\begin{array}{l}\text { Electric log } \\
\text { Microfauna } \\
\text { Lithologic }\end{array}$ \\
\hline P-T1-56 & +59 & 754 & $0-19$ & $19-38$ & $38-104$ & $104-162$ & $162-440$ & $440-600$ & $600-754+$ & - & $\begin{array}{l}\text { Electric log } \\
\text { Microfauna } \\
\text { Lithologic }\end{array}$ \\
\hline NH-T1-61 & +68 & 480 & $0-48$ & - & - & - & - & $48-136$ & $136-280$ & $\frac{280}{\text { Granite }}$ & $\begin{array}{l}\text { Gamma log } \\
\text { Microfauna } \\
\text { Lithologic }\end{array}$ \\
\hline NH-T3-61 & +70 & 294 & $0-51$ & - & - & - & - & $51-131$ & $131-282$ & $\frac{282}{\text { Granite }}$ & $\begin{array}{l}\text { Gamma log } \\
\text { Microfauna } \\
\text { Lithologic }\end{array}$ \\
\hline H-T1-62 & +111 & 345 & $0-40$ & $40-82$ & - & - & - & $82-242$ & $242-340$ & $\frac{340}{\text { Unakite }}$ & $\begin{array}{l}\text { Electric log } \\
\text { Microfauna } \\
\text { Lithologic }\end{array}$ \\
\hline H-T2-62 & +98 & 342 & $0-28$ & $28-70$ & - & - & - & $70-254$ & $254-338$ & $\frac{338}{\text { Unakite }}$ & $\begin{array}{l}\text { Electric log } \\
\text { Microfauna } \\
\text { Lithologic }\end{array}$ \\
\hline H-T3-62 & +96 & 356 & $0-37$ & $37-86$ & - & - & - & $86-258$ & $258-346$ & $\frac{346}{\text { Gneiss }}$ & $\begin{array}{l}\text { Electric log } \\
\text { Microfauna } \\
\text { Lithologic }\end{array}$ \\
\hline H-T2-61 & +58 & 251 & $0-16$ & - & - & - & - & $16-100$ & $100-247$ & $\frac{247}{\text { Granite }}$ & $\begin{array}{l}\text { Electric log } \\
\text { Microfauna } \\
\text { Lithologic }\end{array}$ \\
\hline H-T4-61 & +59 & 246 & $0-14$ & - & - & - & - & $14-82$ & $82-240$ & $\frac{240}{\text { Granite }}$ & $\begin{array}{l}\text { Electric log } \\
\text { Microfauna } \\
\text { Lithologic }\end{array}$ \\
\hline
\end{tabular}

Table 1.-Correlation of Strata in North Carolina Wells.

1. Fossiliferous, variegated, grayish-green to reddish-brown shale and interlayered gray to greenish pink and white sandstone. Accessory minerals include siderite (rare), glauconite (rare), hematite aggregates (common), and mica (abundant). Lignite occurs as scattered particles in the shales. Contains ostracodes and rarely arenaceous Foraminifera.
2. Fossiliferous, black to light gray waxy shale interlayered with tan to gray-colored sandstone. Chalky, coarse, broken and abraded shell fragments (chiefly oysters) may comprise as much as 30 percent of individual samples. Accessory minerals include siderite (common), pyrite (rare), glauconite (common to rare), and mica (abundant). Lignite is common to abundant. Contains 
ostracodes, arenaceous Foraminifera, and scattered fish bones.

3. Unfossiliferous, poorly-sorted pea gravel interlayered with red to brown sideritic sandstone and mudstone. Siderite, gray-brown, and yellow in color, occurs as rosettes, bladed aggregates, and globular aggregates that comprise a few grains to as much as 80 percent of individual samples. Accessory minerals include blood-red hematite aggregates (abundant), pyrite both as euhedral crystals and cementing material (common), and mica (common).

The overlying sediments of the Tuscaloosa Formation of Late Cretaceous age resemble the upper part of the Lower Cretaceous rocks in color and gross composition. However, siderite is absent in the Tuscaloosa Formation in this area. In addition, the Tuscaloosa Formation in the area contains milky-white chalcedony and crenulate green mica (chloritic ?) aggregates that serve to differentiate it from underlying rocks.

Wells, from which Ostracoda of Lower Cretaceous age are described, are located in Figure 1, and include the following:

1. Lenoir County, E. I. Dupont, water well (LE-T6-55) : lat $35^{\circ} 21^{\prime} 30^{\prime \prime}$ N.; long $77^{\circ} 27^{\prime} 00^{\prime \prime}$ W.
2. Pitt County, City of Greenville, water well (P-T1-56) : lat $35^{\circ} 35^{\prime} 30^{\prime \prime}$ N.; long $77^{\circ} 22^{\prime} 15^{\prime \prime} \mathrm{W}$.

3. Northampton County, North Carolina State Highway Commission, Odom Prison Farm, test well (NH-T161):

lat $36^{\circ} 20^{\prime} 45^{\prime \prime} \mathrm{N}$.; long $77^{\circ} 29^{\prime} 15^{\prime \prime} \mathrm{W}$.

4. Northampton County, North Carolina State Highway Commission, Odom Prison Farm, test well (NH-T361) :

lat $36^{\circ} 20^{\prime} 46^{\prime \prime} \mathrm{N}$.; long $77^{\circ} 29^{\prime} 15^{\prime \prime} \mathrm{W}$.

5. Halifax County, City of Scotland Neck, test well (H-T1-62) :

lat $36^{\circ} 07^{\prime} 30^{\prime \prime} \mathrm{N}$.; long $77^{\circ} 25^{\prime} 00^{\prime \prime} \mathrm{W}$.

6. Halifax County, City of Scotland Neck, test well ( $\mathrm{H}-\mathrm{T} 2-62)$ :

lat $36^{\circ} 07^{\prime} 30^{\prime \prime} \mathrm{N}$.; long $77^{\circ} 24^{\prime} 58^{\prime \prime} \mathrm{W}$.

7. Halifax County, City of Scotland Neck, test well (H-T3-62) :

lat $36^{\circ} 07^{\prime} 30^{\prime \prime} \mathrm{N}$.; long $77^{\circ} 24 ’ 59^{\prime \prime} \mathrm{W}$.

8. Halifax County, North Carolina State Highway Commission, Caledonia Prison Farm, test well (H-T2-61) : lat $36^{\circ} 18^{\prime} 15^{\prime \prime} \mathrm{N}$.; long $77^{\circ} 27^{\prime} 15^{\prime \prime} \mathrm{W}$.

9. Halifax County, North Carolina State Highway Commission, Caledonia Prison Farm, test well (H-T4-61) : lat $36^{\circ} 18^{\prime} 15^{\prime \prime} \mathrm{N}$.; long $77^{\circ} 27^{\prime} 16^{\prime \prime} \mathrm{W}$.

The occurrence of species in individual wells is presented in table 2. 


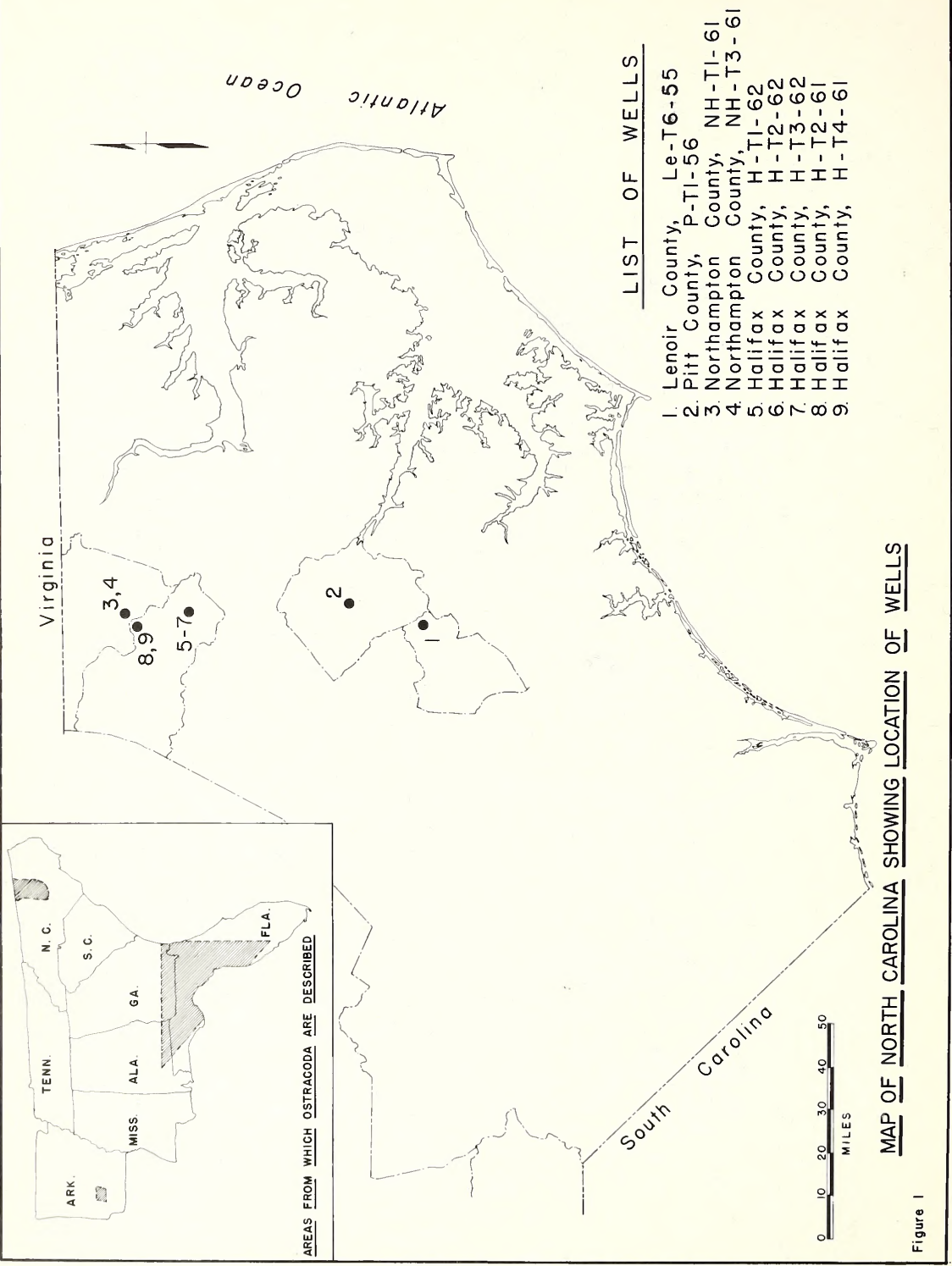


Ostracoda

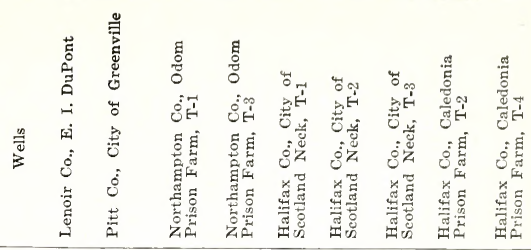

Clithrocytheridea halifaxensis Swain and Brown, n. sp.

Cythereis pittensis Swain and Brown, n. sp.

\begin{tabular}{|c|c|c|c|c|c|c|c|c|}
\hline & & & & & & & $\mathrm{x}$ & $x$ \\
\hline & $\mathrm{x}$ & & & & & & & \\
\hline \multicolumn{9}{|l|}{$\mathrm{x}$} \\
\hline & & & & & & & & $x$ \\
\hline & \multicolumn{8}{|l|}{$\mathrm{x}$} \\
\hline & \multicolumn{8}{|l|}{$\mathrm{x}$} \\
\hline & \multirow[t]{2}{*}{$\mathrm{x}$} & $\mathrm{x}$ & & & & & $\mathrm{x}$ & $\mathrm{x}$ \\
\hline & & \multicolumn{7}{|l|}{$\mathrm{x}$} \\
\hline $\mathrm{x}$ & $\mathrm{x}$ & $\mathrm{x}$ & $\mathrm{x}$ & $\mathrm{x}$ & $\mathrm{x}$ & $\mathrm{x}$ & $\mathrm{x}$ & $\mathrm{x}$ \\
\hline \multicolumn{9}{|l|}{$\mathrm{x}$} \\
\hline & & $\mathrm{x}$ & & & & & & $\mathrm{x}$ \\
\hline & & $\mathrm{x}$ & & & & & $\mathrm{x}$ & \\
\hline
\end{tabular}

Cythereis sp. aff. C. glabrella Triebel

Dolocytheridea? caledonensis Swain and Brown, n. sp.

Eocytheropteron greenvillensis Swain and Brown, n. sp.

Eocytheropteron venoides Swain and Brown, n. sp.

Eucythere semiglypta Swain and Brown, n. sp.

Eucytheroides pustulosa (Swain)

Fossocytheridea lenoirensis Swain and Brown, n. sp.

Haplocytheridea multiclefta Swain and Brown, n. sp.

Orthonotacythere delicatula Swain and Brown, n. sp.

Perissocytheridea odomensis Swain and Brown, n. sp.

Table 2.-Occurrence of Ostracoda in North Carolina wells discussed in this report.

\section{Ostracoda from the Atkinson Formation}

The subsurface Atkinson Formation of southern Alabama, northern Florida, and Georgia was named and described by Applin and Applin (1947) to include those sediments lying between beds of basal Austin age, above, and beds of Early Cretaceous age (undifferentiated), below. Three members comprised the Atkinson Formation and were designated lower member, middle member, and upper member, respectively. In 1955, the Atkinson Formation was redefined (Applin, p. 187) to include just two members, the lower member and the upper member, respectively. The lower member included the lower and middle member of former (1947) usage, and was correlated with the Woodbine of Texas. The upper member remained the upper member of former (1947) usage and was correlated with the Eagle Ford of Texas. In general, the Atkinson Formation is equivalent to the Tuscaloosa Formation and, in part, to the overlying lower part of the Eutaw (restricted).

Specific details concerning correlation of the Atkinson Formation with sedimentary units in other areas are given in Applin and Applin (1947), Applin (1955), and Murray (1961).

The upper member of the Atkinson Formation, that contains a fauna of Eagle Ford age and ranges in thickness from 500 to 1,000 feet, occurs in three depositional facies as follows:

1. Unfossiliferous red shales and poorly sorted gravels of littoral or non-marine origin.

2. Sand and minor shale, greenish gray in color, that contains mollusk fragments and probably is of shallow water marine origin.

3. Flaky shale, dark green in color, and finegrained sandstone containing mollusks and an Eagle Ford microfauna that represents an offshore marine environment.

The following Ostracoda were obtained from the upper member of the Atkinson Formation: Cytherella tuberculifera Alexander, Haplocytheridea lunarea Swain and Brown, n. sp., Brachycythere nausiformis Swain, and Cythereis quadrialira Swain.

The lower member of the Atkinson Formation, that contains a fauna of Woodbine age and ranges 
in thickness from 60 to 700 feet, also occurs in three depositional facies as follows:

1. Dark-gray to greenish-gray flaky shale and dark brownish-gray-to black splintery shale commonly containing thin lenticular beds of sandstone that may be glauconitic and fossiliferous and represents a marine facies.

2. Poorly sorted micaceous sandstone interbedded with varicolored sideritic shale that represents a littoral facies.

3. Dark-gray to black micaceous and arenaceous shale and fine-grained sandstone that represents a marine facies.

The collection of Ostracoda submitted by the Applins included specimens designated as "middle and lower Atkinson" undifferentiated.

This terminology of former (1947) usage is here remanded to the terminology of current (1955) usage and specimens labeled "middle and lower Atkinson" are recorded in this paper as occurring in the lower member of the Atkinson Formation as redefined (Applin, 1955, p. 187).

The following Ostracoda were obtained from the lower member of the Atkinson Formation: Cytherella beyrichoides Swain and Brown, n. sp., Cytherella austinensis Alexander, Bairdia comanchensis Alexander, Bairdia ? sp., Paracypris goodlandensis Howe and Laurencich, Paracypris alta Alexander, Paracypris sp., Paracyprideis ? graysonensis (Alexander), Schuleridea washitaensis (Alexander), Cythereis eaglefordensis Alexander, Cythereis sp., Cythereis fredericksburgoides Swain and Brown, n. sp., Alatacythere tokiana? (Israelsky), Eocytheropteron cf. tumidum (Alexander), Eocytheropteron semiconstrictum? Alexander, Centrocythere annulopapillata Swain and Brown, n. sp., and Cytherelloidea ontovariosa Swain and Brown, n. sp.

Wells from which Atkinson Ostracoda were submitted are located in Figure 2 and include the following:

\section{Alabama}

1. Union Producing Company's No. 1 Kirkland well; NE NE sec. 20, T. 7N., R. 11W., Houston County, Alabama; drill-cutting sample 3,709-3,711 feet.
2. Escambia Oil Company's No. 1 State Line Land and Lumber Company well; 375 feet $\mathrm{S}$ and 330 feet $\mathrm{W}$ NE cor. NW SW, sec. 24, T. 1N., R. 10E., Escambia County, Alabama; core sample 4,679-4,684 feet.

\section{Florida}

3. Sun Oil Company's No. 1 Tillis well, SE SW, sec. 28, T. 28., R. 15E., Suwannee County, Florida; core sample $3,240-3,250$ feet.

4. Sun Oil Company's No. 1 Westbury well; 14, 789.09 feet $\mathrm{S}$ and $4,927.42$ feet $\mathrm{E}, \mathrm{NW}$ cor, sec. 37, T. 11S., R. 26E., Putnam County, Florida; core sample 3,834-3,838 feet.

5. Humble Oil Company's No. 1 Tindel well, C NW NE, sec. 8 , T. 5N., R. 11W., Jackson County, Florida; core samples 2,881-2,891 feet and 3,470-3,500 feet.

6. Sun Oil Company's No. 1 Johnson well; SE SE NE, sec. 27, T. 4S., R. 16E., Columbia County, Florida; core sample 2,955-2,965 feet.

7. Sun Oil Company's No. 1 Russell well; SW NE NE, sec. 8, T. 5S., R. 15E, Suwannee County, Florida; core sample 3,070-3,080 feet.

8. Humble Oil Company's No. 1 Cone well, SE NW sec. 22, T. 1N., R. 17E., Columbia County, Florida; core sample 3,548-3,556 feet.

9. Coastal Petroleum Company's No. 1 Larsh well; SW NE SW, sec. 1, T. 2S., R. 3E., Jefferson County, Florida; core sample 3,445-3,451 feet.

10. Coastal Petroleum Company's No. 1 Wright well; SE cor. sec. 7, T. 30S., R. 17 E., Pinellas County, Florida; core sample 7,100-7,107 feet.

11. Sun Oil Company's No. 1 P. C. Crapps "A" well; NW NE, sec. 36, T. 8S., R. 10E., Dixie County, Florida; core sample 3,548-3,556 feet.

12. Magnolia Petroleum Company's No. 5B State Block 1A well; Offshore Blk. 5B, 15,009.9 feet S, $43^{\circ} 52^{\prime} 5$ " $\mathrm{W}$ of USC\&G Triangulation Station Sand 2, 1935 , on shore of mainland near SW cor. sec. 6, T. 9 S., R. 8 W., and 9,559 feet $\mathrm{S}, 21^{\circ} 41^{\prime} 45^{\prime \prime} \mathrm{E}$ of USC\&G Triangulation Station Hoppe 2, 1935 on shore of mainland approximately $1 / 2$ mile $\mathrm{E}$ of $\mathrm{SW}$ cor. of fractional sec. 10, T. 9S., R. 9W., Franklin County, Florida; core sample 5,138-5,144 feet.

\section{Georgia}

13. Sun Oil Company's No. 1 Barlow well, SW NE SW, Lot 373,12 th. Land District, Clinch County, Georgia; core sample 3,709-3,711 feet.

14. Humble Oil and Refining Company's No. 1 Bennett and Langdale well, 660 feet $\mathrm{S}$ and 660 feet $\mathrm{E}$ of NW cor. Land Lot No. 146, 12th. Land District, Echols County, Georgia; core samples 3,690-3,700 feet and 3,700-3,710 feet.

The occurrence of species in individual wells is given in table 3. 


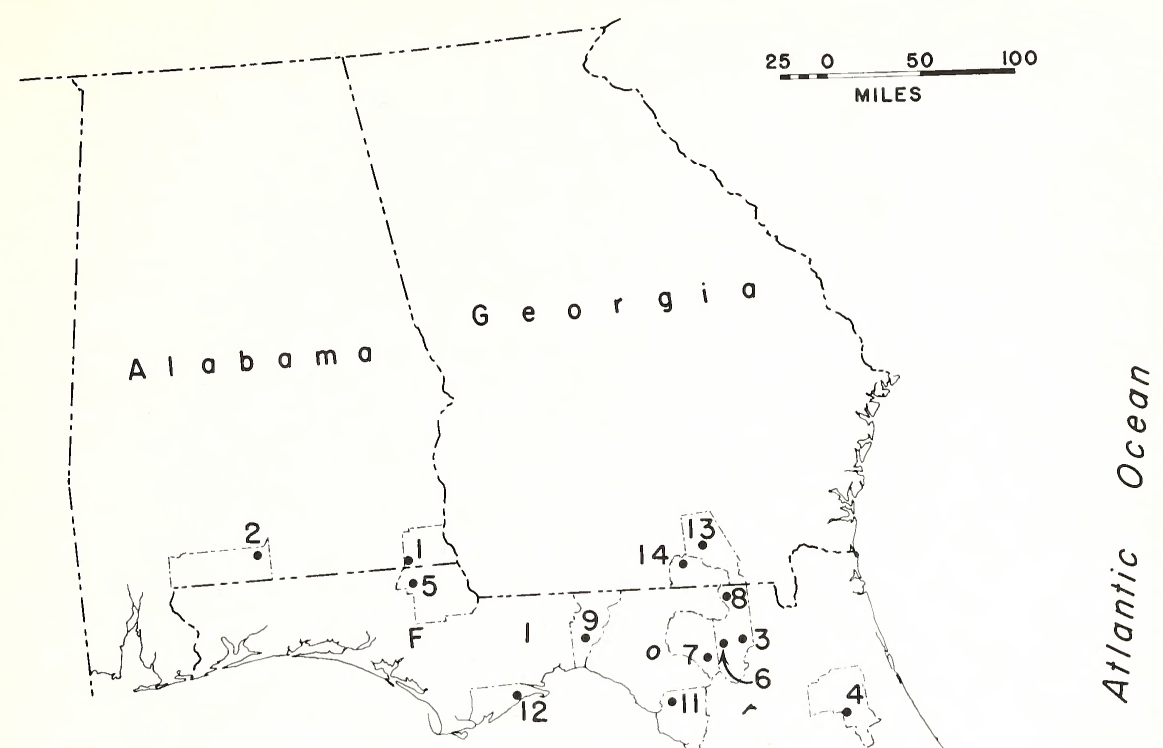

Gulf of Mexico

\section{LIST OF WELLS}

1. Kirkland No.I

2. State Line Land and Lumber No. I

3. Tillis No.I

4. Westbury No.1

5. Tindel No.I

6. Johnson No.I

7. Russell No.I

8. Cone No.I

9. Larsh No.I

10. Wright No.1

11. Crapps "A" No.1

12.State Block IA, No.5B well

13.Barlow No.I

14.Bennett and Langsdale No. I

MAP OF ALABAMA, FLORIDA, AND GEORGIA

Figure 2 SHOWING LOCATION OF WELLS 
Ostracoda

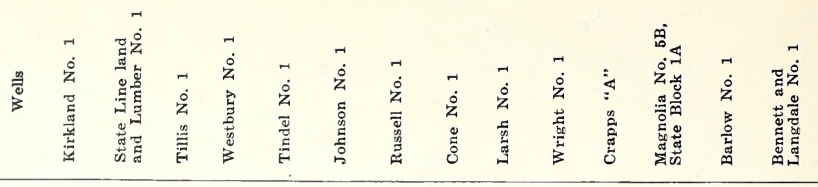

Alatacythere tokiana (Israelsky)?

Bairdia comanchensis Alexander

Bairdia ? sp.

$\mathrm{x}$

Brachycythere nausiformis Swain

Cythereis eaglefordensis Alexander

Cythereis fredericksburgoides Swain and

Brown, n. sp.

Cythereis quadrialira Swain

Cythereis sp.

Cytherella austinensis Alexander

Cytherella beyrichoides Swain and Brown, n. $\mathrm{sp}$.

Cytherella tuberculifera Alexander

Cytherelloidea ontovariosa Swain and

Brown, n. sp.

Eocytheropteron cf. tumidum Alexander

Eocytheropteron semiconstrictum Alexander ?

Haplocytheridea lunarea Swain and Brown, n. sp.

Centrocythere annulopapillata Swain and

Brown, n. sp.

Paracyprideis ? graysonensis (Alexander)

Paracypris alta Alexander

Paracypris goodlandensis Howe and

Laurencich

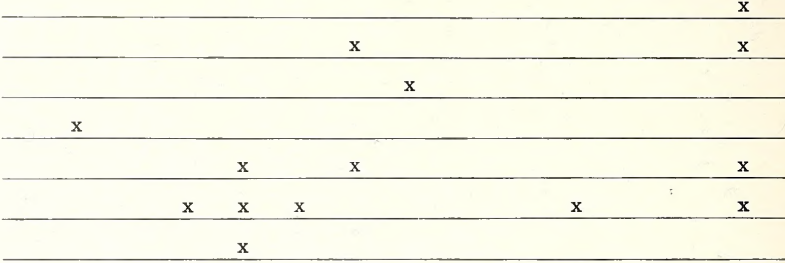

Paracypris sp.

Schuleridea washitaensis (Alexander)

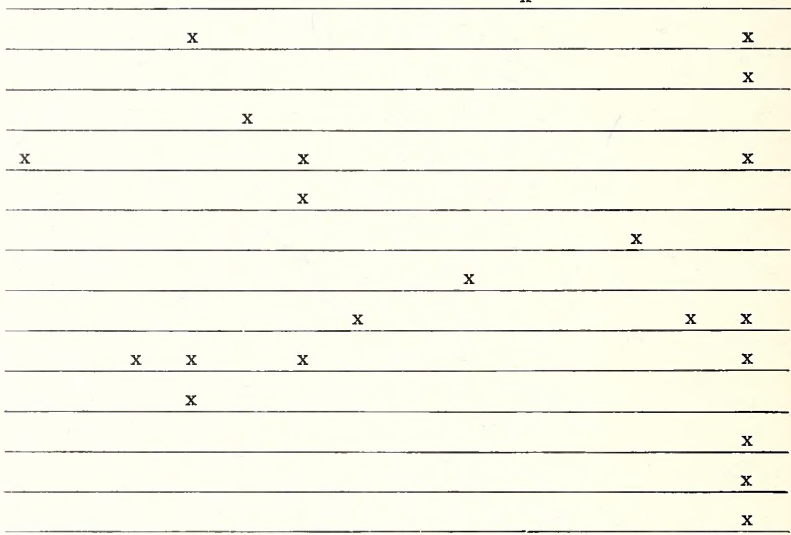

Table 3.-Occurrence of Ostracoda in Alabama, Florida, and Georgia Wells.

\section{Trinity Ostracoda Described by Vanderpool}

Several species from the Lower Cretaceous Trinity Group of northern Texas and northern Louisiana were described by Vanderpool (1928, 1937) and more recently the species were reconsidered by Howe and Laurencich (1958). Swain examined Vanderpool's types in the U. S. National Museum and felt that it would be appropriate to reillustrate and redescribe the species. The following ostracodes from the Lower Cretaceous Trinity group are redescribed in this paper:

Asciocythere perforata (Vanderpool)

Asciocythere rotunda (Vanderpool)

Cypridea dequeenensis Swain and Brown, n. sp.

Cypridea diminuta Vanderpool

Cypridea wyomingensis Jones
Cythereis praeornata Swain and Brown, n. name.

Eocytheropteron trinitiensis (Vanderpool)

Paracypris cf. P. angusta Alexander

Paracypris weatherfordensis Vanderpool

Schuleridea dorsoventrus (Vanderpool)

\section{Systematic Descriptions Of Ostracoda}

Order Podocopida Müller, 1894

Suborder Platy copina Sars, 1866

Family Cy therellidae Sars, 1866

Genus Cytherella Jones, 1849

Cytherella beyrichoides Swain and Brown, n. sp.

Plate 1, Figure 1; Text Figure 3a

Cytherella beyrichi (Reuss), Schmidt, 1948, Jour. Paleont., v. 22, p. 406, pl. 61, fig. 2. 
Shell elongate-elliptical in lateral view, highest medially; dorsal margin gently convex; ventral margin mostly straighter than dorsum, in a few instances, as in illustrated specimen, it is about equal in convexity to dorsum; anterior margin broadly and nearly uniformly rounded; posterior margin more narrowly rounded, slightly extended medially. Right valve larger, extending beyond left most strongly along dorsum and venter. Valves rather compressed, thickest in posterior half; female dimorphs slightly wedge-shaped in dorsal view, tapering toward anterior. Surface weakly and minutely punctate, a weak sulcus occurs mid-dorsally. In mature shells, mid-longitudinal section of valve forms a broad ridgelike swelling, in molts swelling is more ventral in position.

Right valve grooved along dorsum for reception of edge of left; a slight groove lies along ventral margin of right valve; terminally, grooves are barely perceptible. Muscle scar not seen clearly owing to condition of preservation of the present specimens.

Length of figured specimen (Pl. 1, Fig. 1) 0.65 $\mathrm{mm}$, height $0.40 \mathrm{~mm}$, convexity $0.25 \mathrm{~mm}$.

Remarks.-The present specimens were compared to hypotypes of Cytherella beyrichi (Reuss) in the U. S. National Museum and found to be different in shape. The specimens identified by Schmidt (1948, p. 406) as C. beyrichi (Reuss) from the Marshalltown and Monmouth Formations of Delaware and Maryland may be the same as the new species. Among other described species from the Cretaceous, C. kansasensis Morrow from the Late Cretaceous Niobrara Chalk is similar to $C$. beyrichoides, n. sp. in elliptical outline, but is apparently less wedge-shaped in dorsal view in the females than is the present species.

Occurrence.-Lower member of Atkinson Formation, Humble Oil and Refining Company, No. 1 Bennett and Langdale well, Echols County, Georgia, core $3,700-3,710$ feet.

\section{Cytherella austinensis Alexander}

Plate 1, Figures 2 a-d

Cytherella obesa Alexander (not Jones and Kirkby, 1884), 1929, Univ. Texas Bull. 2907, p. 51, pl. 1, figs. 3, 6. (female, fide Howe and Laurencich, 1958, p. 244)

Cytherella austinensis Alexander, 1929, Univ.
Texas Bull. 2907, p. 51, pl. 2, figs. 4, 6 (male, fide Howe and Laurencich, 1958, p. 244)

Cytherella bullata Alexander, 1932, Jour. Paleont., v. 6, p. 305 , pl. 28 , figs. 3,4 (new name for $C$. obesa Alexander, not Jones and Hinde)

Loetterle, 1937, Nebr. Geol. Surv. 2nd Sec. Bull., 12 , p. 50 , pl. 8 , figs. 4 a, b.

Shaver, 1953, Jour. Paleont., v. 27, p. 471-480, 3 figs.

? Cytherella sp. Schmidt, 1948, Jour. Paleont., v. 22, p. 406, pl. 61, figs. 4-6.

Cytherella cf. C. obesa Alexander, Swain, 1952,

U. S. Geol. Survey Prof. Paper 224-B, p. 68, pl. 8, fig. 2 .

Shell subelliptical in side view, highest at or slightly posterior to midlength; dorsal margin gently convex; ventral margin nearly straight; terminal margins nearly equally rounded. Right valve extends strongly beyond left dorsally and ventrally, less strongiy terminally; greatest extension is mid-dorsal, where right valve is slightly umbonate. Valves moderately convex, thickest in posterior half. Surface smooth.

Right valve with strongly incised shelf along dorsal and ventral margins for reception of edge of left; terminally, incisions are much shallower. Muscle scar a large group of radially arranged spots lying anterior to middle.

Dimorphism exhibited posteriorly by relatively more tumid female shells, in contrast with the more compressed males; females bear a low broad transverse median interior swelling and a corresponding shallow external depression.

Length of figured specimen (Pl. 1, Fig. 2a) 0.69 $\mathrm{mm}$, height $0.44 \mathrm{~mm}$, convexity $0.33 \mathrm{~mm}$.

Remarks.-The specimens studied here are like C. austinensis Alexander in general shape, and particularly in the rather umbonate right valve; the venter of $C$. austinensis, perhaps, is more convex than in the present specimens. C. austinensis occurs in the upper part of the Austin Chalk and as high as the Pecan Gap Chalk Member of Taylor Marl in Texas (Alexander, 1929, p. 51). Closely related, if not identical specimens were recorded by Schmidt (1948, p. 406) from both the Eocene and the Upper Cretaceous rocks of the Middle Atlantic states.

Occurrence.-Lower member of Atkinson Formation, Humble Oil and Refining Company, No. 1 Bennett and Langdale well, Echols County, Georgia, core 3,690-3,700 and 3,700-3,710 feet; Sun Oil Company, No. 1 Westbury well, Putnam County, Florida, core 3,834-3,838 feet. 

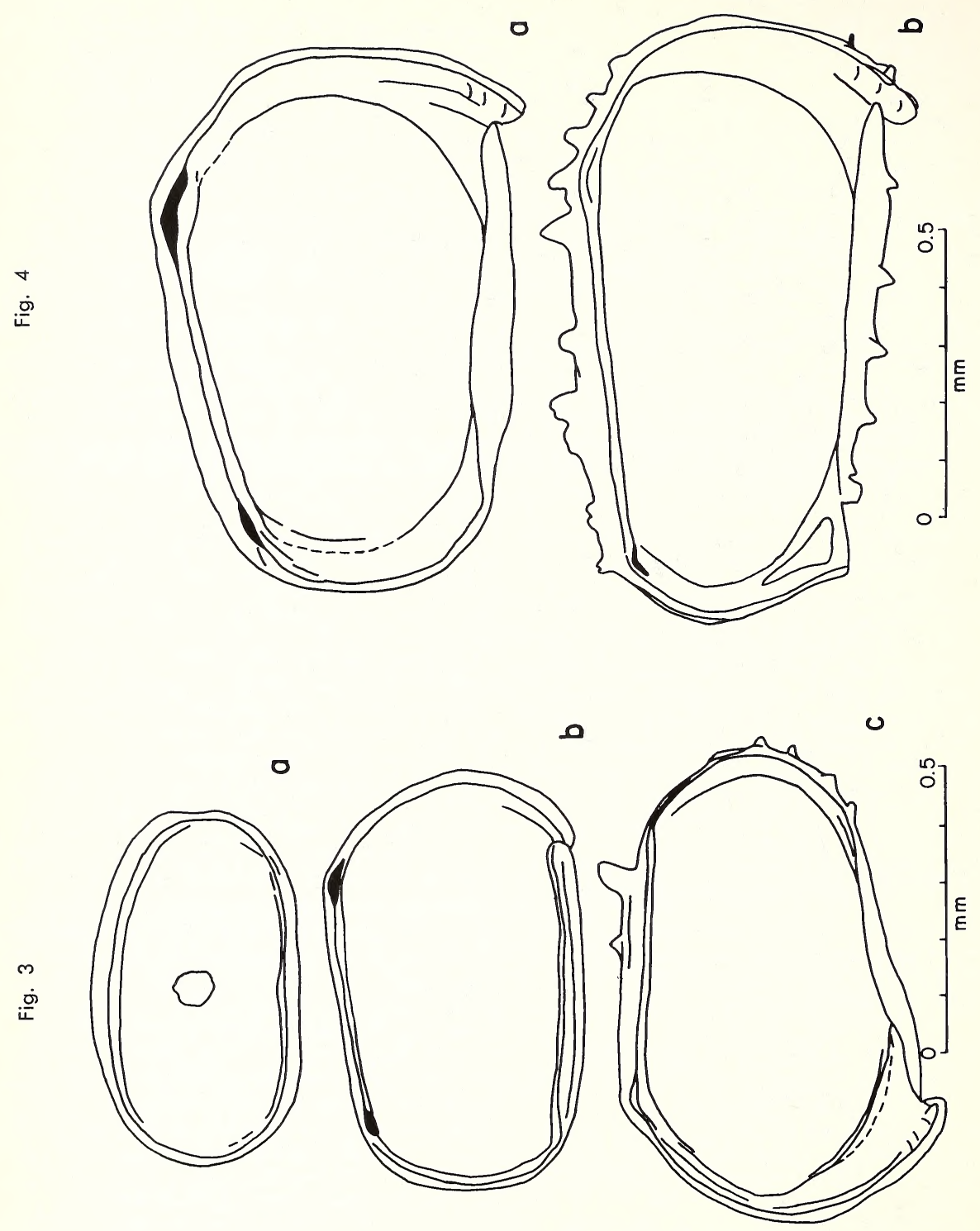
3a. Cytherella beyrichoides Swain and Brown, n. sp., interior of holotype right valve, lower member of Atkinson Formation, Humble Oil and Refining Company's No. 1 Bennett and Langdale well, Echols County, Georgia, 3,700-3,710 feet

3b. Cypridea diminuta Vanderpool, interior of paratype left valve, DeQueen Limestone, Gypsum Bluff, Arkansas

3e. Cypridea dequeenensis Swain and Brown, n. sp., interior of paratype right valve, DeQueen Limestone, Gypsum Bluff, Arkansas

Figure 4.

Page

4a. Cypridea dequeenensis Swain and Brown, n. sp., interior of holotype left valve, DeQueen Limestone, Gypsum Bluff, Arkansas

4b. Cypridea wyomingensis Jones, interior of a left valve, DeQueen Limestone, Gypsum Bluff, Arkansas 


\section{Cytherella tuberculifera Alexander}

Plate 1, Figures $3 \mathbf{a}, \mathbf{b}$

Cytherella tuberculifera Alexander, 1929, Univ. Texas Bull. 2907, p. 52, pl. 2, fig. 2; 1934, Jour. Paleont., v. 8, p. 212.

Butler and Jones, 1957, Louisiana Dept. Cons. Geol. Bull. 32, p. 9, pl. 6, fig. 7 .

Howe and Laurencich, 1958, Introd. Study Cretaceous Ostracoda, p. 257, text fig.

The species was described in detail by Alexander and by Butler and Jones and the present specimens fit the earlier descriptions. The diagnostic features are the ovate outline, strong right valve overlap, and posterior marginal blunt projection of right valve.

Length of figured specimen $0.70 \mathrm{~mm}$, height $0.42 \mathrm{~mm}$, convexity $0.32 \mathrm{~mm}$.

Occurrence.-The species is rare in strata assigned an Eagle Ford (upper member of Atkinson) age by P. L. and E. Applin (written communication) in the Humble Oil and Refining Company's Tindel No. 1 well, Jackson County, Florida, core sample 2,881-2,891 feet. The species has been recorded previously from the Paleocene Midway and Upper Cretaceous Navarro Group, of North Texas, the Upper Cretaceous of North Carolina, and in beds assigned a Late Cretaceous Saratoga age from Prothro Salt Dome, Bienville Parish, Louisiana (Butler and Jones, 1957, p. 9). The present occurrence in Eagle Ford equivalents extends the species considerably farther down in the Cretaceou than heretofore recorded:

Genus Cytherelloidea Alexander, 1929

Cytherelloidea ontovariosa Swain and Brown, n. sp.

Plate 1, Figures 4a-e

Shell subquadrate in lateral view; dorsal margin nearly straight with posterocardinal angle less obtuse than anterocardinal angle; ventral margin slightly concave medially, passing more abruptly into posterior than into anterior margin; terminal margins broadly rounded, posterior truncated. Right valve larger than left, extending beyond the other most noticeably along ventral and midportion of dorsal margins. Valves compressed, thickest posteriorly.

Anterior margin of each valve bears a high marginal rim, broad at the base, narrow-crested, terminating a little posterior to anterior marginal bend, continuing as a much lower ridge along venter to posterior end; a discontinuous, irregular narrow ridge rises near posterocardinal angle and trends obliquely forward to anteroventral region; posterior end bears strongly elevated rim that overhangs outer valve margin; ventral and dorsal to midheight, on inner flank of posterior ridge, are two node-like elevations both of which continue anteriorly as narrow ridges; the more dorsal of two ridges terminates near midlength, the other extends forward nearly to anterior marginal rim; dorsal to last mentioned ridge, yet ventral to midheight is an additional short, weak, longitudinal ridge. A shallow excavation, or pit, occupies a slightly dorsomedian position. General surface in adult rather weakly pitted.

Immature molts are much more coarsely pitted in comparison to their size than adult shells; the surface ridges are narrower and lower; the two posterior nodes are weakly developed and the ventromedian surface of the valve, particularly in posterior portion, is swollen. In smallest molts the medium excavation is represented by a shallow sulcus in dorsal half of valve (pl. 1, fig. 4a).

Length of holotype (Pl. 1, Fig. 4a) $0.66 \mathrm{~mm}$, height $0.36 \mathrm{~mm}$, thickness $0.22 \mathrm{~mm}$.

Relationships.-The pattern of surface ridges in this species serves to distinguish it from other described members of the genus. C. reticulata Alexander (1929, p. 57) from the Weno Clay and upper part of the Denton Clay of the middle Washita Group of Texas is similar in general distribution of surface ridges, but lacks the oblique mid-dorsal ridge.

Occurrence.-Lower member of Atkinson Formation in the following wells: (1) Humble Oil and Refining Company, No. 1 Bennett and Langdale well, Echols County, Georgia, cores 3,690-3,700 and 3,700-3,710 feet; (2) Union Producing Company, No. 1 Kirkland well, Houston County, Alabama, cuttings 3,280-3,290 feet; (3) Sun Oil Company, No. 1 Johnson well, Columbia County, Florida, core 2,955-2,965 feet.

\section{Suborder Podocopina Sars, 1866}

Superfamily Bairdiacea Sars, 1888

Family Bairdiidae Sars, 1888

Genus Bairdia McCoy, 1844

Bairdia comanchensis Alexander

Plate 1, Figures 5a-c

Bairdia comanchensis Alexander, 1929, Univ. Texas Bull. 2907, p. 63, pl. 2, fig. 15, pl. 3, fig. 4. 
Howe and Laurencich, 1958, Introd. Study Cretaceous Ostracoda, p. 66, text fig.

Shell triangular-ovate, highest medially, height a little more than half length; dorsal margin strongly and more or less evenly convex; ventral margin gently convex in left valve, sinuous in right; anterior margin narrowly rounded, extended medially, curved below, truncated above; posterior margin produced below as rather strong subacute beak. Left valve larger than right, extending strongly beyond right along dorsum, anterior and posterior slopes and midventer, little or no extension terminally. Surface smooth.

The hinge consists of a groove in the hinge face of the left valve into which fits edge of right valve. Along dorsal slopes, crenulations that are characteristic of Bairdoppilata Coryell, Sample and Jennings are lacking. Inner lamellae of moderate width, with line of concrescence and inner margin slightly separated terminally. Other internal features obscured by recrystallization and by matrix.

Length of figured specimen (Pl. 1, Fig. 5a) $0.92 \mathrm{~mm}$, height $0.55 \mathrm{~mm}$, convexity $0.43 \mathrm{~mm}$.

Remarks.-The present specimens conform to most of the characteristics prescribed for the species by Alexander, but some of the Atkinson shells are finely pitted. Apparently this is a matter of preservation, because the more weakly pitted shells mostly appear to be abraded or recrystallized.

Occurrence.-Lower member of Atkinson Formation in the following wells: (1) Humble Oil and Refining Company's No. 1 Bennett and Langdale well, Echols County, Georgia, core samples 3,7003,710 feet; (2) Sun Oil Company's No. 1 Russell, Suwannee County, Florida, core samples 3,0703,080 feet. The species was described as rare in the upper part of the Denton and lower part of the Weno Formations, middle Washita Group of northeastern Texas.

\section{Bairdia ? sp. \\ Plate 1, Figure 6}

Shell subtriangular in side view, highest medially; dorsal margin strongly convex, subacuminate medially; ventral margin gently convex, somewhat sinuous; anterior margin narrowly rounded, extended below; posterior margin acuminate, strongly extended below. Left valve moderately convex. Surface smooth.
Length of figured left valve $0.97 \mathrm{~mm}$, height $0.65 \mathrm{~mm}$, convexity of valve $0.33 \mathrm{~mm}$.

Remarks.-No definite comparisons can be made between this form and described species because only the left valve has been found. The strongly convex dorsum and general outline are suggestive of Bairdoppilata acuticauda (Veen) (1934, p. 8) or Bairdia pseudocretacea Veen $(1934$, p. 8) both of Late Cretaceous age.

Occurrence.-Lower member of Atkinson Formation, Humble Oil and Refining Company No. 1 Cone well, Columbia County, Florida, core sample 3,545-3,556 feet.

\section{Superfamily Cypridacea Baird, 1845}

Family Paracyprididae Sars, 1923

Genus Paracypris Sars, 1866

Paracypris goodlandensis Howe and Laurencich

Plate 1, Figures 7 a-c

Paracypris siliqua Jones and Hinde. Alexander, 1929, Univ. Texas Bull. 2907, p. 64, pl. 3, figs. 11, 13.

Paracypris goodlandensis Howe and Laurencich, 1958, Introd. Study Cretaceous Ostracoda, p. 448 , text fig.

Shell elongate-sublanceolate in side view, highest about three-eighths from anterior end; dorsal margin moderately convex, truncated posterior to position of greatest height and with broadly obtuse posterior cardinal angle in some specimens, evenly rounded in others; ventral margin long and nearly straight, slightly concave in midportion; anterior margin rounded with greatest extension ventral to midheight; posterior margin acuminate ventral to midheight. Left valve larger than right, overlapping and extending beyond the other most conspicuously along venter, less so along dorsum and dorsal slopes. Surface smooth.

Hinge edge of right valve smooth and simple, apparently overlapped slightly by edge of left. Inner lamellae very broad terminally, although partly concealed in single separated right valve at hand. Muscle scar not observed (Pl. 1, Fig. 7a).

Length of a figured specimen (Pl. 1, Fig. 7a) $0.87 \mathrm{~mm}$, height $0.35 \mathrm{~mm}$, thickness $0.17 \mathrm{~mm}$.

Remarks.-The truncation of the dorsal margin and the slightly concave venter in the present specimens relate them to $P$. goodlandensis Howe and Laurencich (1958, p. 448) from the upper two-thirds of the Goodland, the Kiamichi, and the 
Grayson Formations of Texas (Alexander, 1929, p. 65).

Occurrence.-Lower member of Atkinson Formation, Humble Oil and Refining Company's No. 1 Bennett and Langdale well, Echols County, Georgia, core sample 3,700-3,710 feet.

\section{Paracypris alta Alexander}

Plate 1, Figures 8 a, b

Paracypris alta Alexander, 1929, Univ. Texas Bull. 2907, p. 66, pl. 3, fig. 9, 12.

Howe and Laurencich, 1958, Introd. to Study of Cretaceous Ostracoda, p. 446, text fig.

Shell elongate-acuminate in side view, highest three-eighths to one-half of distance from anterior end; dorsal margin moderately convex, truncated anterior to greatest height; ventral margin gently concave; anterior margin rounded, slightly extended below; posterior margin very strongly extended and acuminately pointed ventral to midheight. Left valve larger than right overlapping and extending beyond the other along ventral and anterodorsal margins. Valves compressed, thickest medially to anteromedially. Internal features not observed.

Length of a figured specimen (Pl. 1, Fig. 8a), that perhaps is incomplete along anterior margin, $0.80 \mathrm{~mm}$, height $0.33 \mathrm{~mm}$, convexity $0.37 \mathrm{~mm}$.

Remarks.-This species can be distinguished from $P$. siliqua Jones and Hinde $(1890$, p. 2$)$ by the more pronounced truncation of the anterodorsal marginal slope; in $P$. siliqua the mid-dorsal region and the posterodorsal slope tend to be truncated.

Occurrence.-Lower member of Atkinson Formation. Sun Oil Company No. 1 Westbury well, Putnam County, Florida, core sample 3,834-3,838 feet.

\section{Paracypris sp. \\ Plate 1, Figure 9a, b}

Shell elongate, subacuminate in side view, highest about three-sevenths from anterior end; dorsal margin moderately and nearly uniformly convex; ventral margin nearly straight, very slightly concave medially; anterior margin rounded, with greatest extension at or slightly ventral to midheight; posterior margin narrowly rounded, subacuminate, strongly extended below midheight. Left valve larger than right, extending most noticeably beyond the other along ventral and anterodorsal margins. Surface smooth. Internal features not observed.

Length of a figured specimen (Pl. 1, Fig. 9a) $0.66 \mathrm{~mm}$, height $0.29 \mathrm{~mm}$, convexity $0.22 \mathrm{~mm}$.

Remarks.-Representatives of this form occur with Paracypris alta Alexander in one of the wells, and may represent either dimorphs or immature molts of that species, rather than a distinct species. The generally larger size, more extended and acuminate posterior end and truncated dorsal margin of $P$. siliqua Jones and Hinde distinguish the present specimens from that species.

Occurrence.-Lower member of Atkinson Formation, Humble Oil and Refining Company, No. 1 Bennett and Langdale well, Echols County, Georgia, core 3,700-3,710 feet.

\section{Paracypris weatherfordensis Vanderpool}

Plate 4, Figures 1a, b

Paracypris weatherfordensis Vanderpool, 1928, Jour. Paleont., v. 2, p. 104, pl. 14, figs. 11, 12 . Howe and Laurencich, 1958, Introd. Study Cretaceous Ostracoda, p. 451, text fig.

Shell elongate, sublanceolate in side view, highest medially; dorsal margin moderately convex, with truncated anterior slope; ventral margin nearly straight, slightly sinuous; anterior margin nearly uniformly rounded; posterior margin bluntly acuminate, strongly extended below. Valves unequal, the left overlapping and extending beyond right except anteroventrally, where overreach is slight or lacking; anterodorsally, a small flaplike extension of left valve results in slightly greater overlap than elsewhere, a similar but weaker flap occurs on anterodorsal slope. Valves compressed, greatest convexity median. Surface smooth. Internal features could not be observed clearly in the type specimens.

Length of holotype (Pl. 4, Fig. 1b) $0.81 \mathrm{~mm}$, height $0.35 \mathrm{~mm}$, convexity $0.25 \mathrm{~mm}$. (specimen partly crushed).

Remarks.-Several of the specimens of the type collection are more elongate than the measured specimen cited by Vanderpool, and have concave venters. These are here referred, tentatively, to $P$. angusta Alexander $(1929$, p. 67$)$.

Occurrence.-Vanderpool reported the species to be abundant in certain clay beds in the Glen Rose Formation west of Weatherford, Parker 
County, Texas, and less abundant in the DeQueen Limestone of Arkansas.

\section{Paracypris cf. P. angusta Alexander \\ Plate 4, Figures 2a, b}

Paracypris angusta Alexander, 1929, Univ. Texas Bull. 2907, p. 67, pl. 4, figs. 3, 7. Howe and Laurencich, 1958, Introd. Study Cretaceous Ostracoda, p. 446, text fig.

? Paracypris aff. P. angusta Alexander. Swain, 1948, Maryland Dept. Geol., Mines and Water Res., Bull. 2, p. 192, pl. 12, fig. 6 .

Shell elongate, subreniform-lanceolate in side view, highest medially; dorsal margin moderately convex, sloping more steeply behind than in front of position of greatest height; ventral margin concave medially; anterior margin uniformly rounded; posterior margin acuminate and strongly extended below. Left valve larger than right overlapping and overreaching right around most if not all of periphery. Valves compressed, greatest convexity median. Surface smooth.

Length of figured specimen (Pl. 4, Fig. 2b) 0.86 $\mathrm{mm}$, height $0.37 \mathrm{~mm}$, convexity $0.20 \mathrm{~mm}$.

Remarks.-The greater elongation, posterior acumination and ventral concavity distinguish this form from $P$. weatherfordensis Vanderpool with which it is associated and with which it was identified by Vanderpool. The present specimens are somewhat less acuminate posteriorly than typical P. angusta, as illustrated by Alexander, but are close to hypotype specimens in the U. S. identified by Alexander. The shape and overlap are closely similar to those of $P$. angusta Alexander from the Taylor Marl of northeastern Texas.

Cccurrence.-Vanderpool's specimens were obtained from the Glen Rose Formation, west of Weatherford, Parker County, Texas. The form identified as $P$. aff. angusta from the subsurface of Maryland may be a different species, as it is less elongate and with truncated dorsal slopes.

Family Ilyocyprididae Kauf mann, 1900

Subfamily Cyprideinae Martin, 1940

Genus Cypridea Bosquet, 1852

Cypridea dequeenensis Swain and Brown, n. sp.

Plate 4, Figure 8; Plate 5, Figures 3a-c

Text Figures 3c, $4 a$

Cypridea ventrosa var. bispinosus Vanderpool, 1928, Jour. Paleont., v. 2, p. 104, pl. 14, figs. 1, 2.

? Cypridea cf. ventrosa bispinosus (Jones). Cal- ahan, 1939, Shreveport Geol. Soc. Guidebook 14th Annual Field Trip, p. 5, pl. 8, figs. 9a, b. not Cypridea bispinosa Jones, 1878, Geol. Mag.,

Dec. 2, v. 5, p. 109, pl. 3, figs. 9, 10.

not Cypridea bispinosa Galeeva, 1955, Cretaceous

Ostracod Succession of Mongolian Peoples Republic p. 36, fig. 1a-g. Lubimova, 1956, VNIGRI, Trans., N. S., No. 93, p. 25, pl. 5, fig. 2a, b, 3a, b, 4 (fide) Howe and Laurencich, 1958, p. 119. Cypridea kleinbergi Galeeva, 1955, op. cit., p. 31, pl. 8, figs. 2a-e ( $=$ C. bispinosa Galeeva by Howe and Laurencich, 1958)

Shell subtrapezoidal in side view, highest about one-fourth from anterior end; hinge margin nearly straight except for projecting spines, about five-sevenths of shell length, obtuse cardinal angles, the anterior sharper but somewhat smaller than posterior; ventral margin slightly convex, converging posteriorly with dorsum and with well defined but shallow notch near anteroventral marginal bend; anterior margin with broad curvature, extended medially, truncated above; posterior margin narrower but also with broad curvature, extended flangelike along posteroventral marginal bend. Left valve larger than right, overlapping and extending beyond right terminally and ventrally; dorsally, right valve extends slightly beyond edge of left. Valves compressed, most convex posteromedially.

Anteroventral submarginal portion of each valve bears a prominent hood, projecting beak, and postjacent furrow which terminates in marginal notch. A large spine projects from surface at midheight, about one-half from posterior end; a second large spine projects beyond dorsal margin from a position dorsal of preceding spine. Generai valve surface coarsely and densely pitted, and with numerous small spines scattered over surface.

Hinge surface of right valve consists of long rabbet-groove and terminal triangular-shaped toothlike elevations; hinge of left valve has corresponding rabbet-groove surface and terminal triangular-shaped depressions over which fits groove in right valve. Inner lamellae rather narrow, with slight vestibule developed terminoventrally. Pore canals and muscle scar not observed because of recrystallization of shell material.

Length of holotype left valve (P1. 4, Fig. 8) $0.93 \mathrm{~mm}$, height $0.60 \mathrm{~mm}$, convexity of valve 0.30 $\mathrm{mm}$, excluding large spines.

Relationships.-A new name is required for 
Vanderpool's species because of prior use of bispinosa for another species of Cypridea. In addition, as pointed out by Howe and Laurenich (1958, p. 141), C. ventrosa Jones has right valve overlap and the present species can not be a variety of it. Several closely related species, characterized by pitted and pustulose surface and by a median to postero-median spine have been described from Asia i.e., C. occollata Lubimova, $C$. polita Galeeva, C. salva Lubimova, C. solida Galeeva, $C$. stellata Galeeva and $C$. valida Galeeva all from the Lower Cretaceous of Mongolia ( $\mathrm{Lu}$ bimova, 1956, p. 20,33,43, 44, 57, 72). All of these differ from the present species in details of shape and ornamentation, but serve as an indication of the general age relations of this kind of Cypridea.

Occurrence. - DeQueen Limestone, Gypsum Bluff near Murpheesboro, Pike County, Arkansas, and rarely in Glen Rose Formation eight miles south of Weatherford, Texas.

\section{Cypridea wyomingensis Jones}

Plate 4, Figure 10; Plate 5, Figures 1a-c

Text Figure $4 \mathrm{~b}$

Cypridea tuberculata var. wyomingensis Jones, 1893, Geol. Mag., Dec. 3, v. 10, p. 386, pl. 15, figs. $5 \mathrm{a}, \mathrm{b} ; 6 \mathrm{a}, \mathrm{b}$.

White, 1895, U. S. Geol. Survey Bull. 128, p. 62, pl. 11, figs. 5a, b; $6 \mathrm{a}, \mathrm{b}$.

Cypridea tuberculata var. gypsumensis Vanderpool, 1928, Jour. Paleont. v. 2, p. 103, pl. 13, figs. 9-12.

Cypridea wyomingensis Jones. Peck, 1941, Jour. Paleont., v. 15 , p. 297 , pl. 43 , figs. $10-17$; 1951 , Jour. Paleont., v. 25, p. 312, pl. 45, figs. 4-7.

Loranger, 1951, Bull. Am. Assoc. Petroleum Geologist, v. 35, p. 2363, pl. 2, fig. 22.

Clark, 1954, West. Canada Sed. Basin, Tulsa, p. 293, pl. 2, fig. 22.

Howe and Laurencich, 1958, Introd. Study Cretaceous Ostracoda, p. 142, text fig.

Cypridea ef. C. wyomingensis Jones. Swartz and Swain, 1946, Jour. Paleont. v. 20, p. 372, pl. 52, figs. 19-22.

The shell of this species has been thoroughly described in several of the publications cited. It is relatively elongate, subquadrate, with well developed anteroventral hood, beak, furrow and notch; surface is coarsely tuberculate or spinose and coarsely and densely pitted; there is a shallow, oblique anterodorsal sulcus.
Remarks.-The authors concur with Howe and Laurencich (1958, p. 142) in referring Vanderpool's specimens to wyomingensis.

Occurrence.-The species has been found in the Lower Cretaceous Bear River Formation of Wyoming, questionably from the Upper Jurassic Schuler Formation of southern Arkansas, and Vanderpool's specimens are from the DeQueen Limestone at Gypsum Bluff, near Murpheesboro, Pike County, Arkansas.

\section{Cypridea diminuta Vanderpool}

Plate 4, Figure 9; Plate 5, Figures 2a-d

\section{Text Figure $3 b$}

Cypridea diminutus Vanderpool, 1928, Jour. Paleont., v. 2, p. 103, pl. 13, figs. 7, 8.

Cypridea diminuta Vanderpool. Peck, 1941, Jour. Paleont., v. 15, p. 298, pl. 44, figs. 29-32; 1951, Jour. Paleont., v. 25, p. 312, pl. 49, fig. 6 .

Howe and Laurencich, 1958, Introd. Study Cretaceous Ostracoda, p. 121, text fig.

Shell small, subquadrate, highest about onefourth from anterior end; dorsal margin nearly straight, projecting slightly at anterior cardinal angle; cardinal angles obtuse, the anterior larger than the posterior; ventral margin nearly straight to slightly convex, with small anteroventral notch, converging posteriorly with dorsum; anterior margin broadly rounded, truncate above; posterior margin with same curvature, but much narrower. Left valve larger than right, overlapping and overreaching along free margins. Valves compressed, most convex medially to posteromedially.

Anteroventral portion of right valve with small narrow submarginal hood, beak, furrow and notch; corresponding area on left valve consists of a small pit in place of furrow and with hood, beak, and notch reduced or absent. General surface very densely pitted in a sievelike pattern, the interspaces only about one-half width of pits; a few small scattered pustules occur on surface. Outer margin of right valve, along venter, bears a row of submarginal, closely spaced, short grooves.

Hinge of left valve consists of a long faintly crenulate groove at either end of which is a small socketlike depression. Inner lamellae narrow, but details of this and other internal structures obscured by recrystallization of shell.

Length of holotype shell selected here (Pl. 4, 
Fig. 9) $0.73 \mathrm{~mm}$, height $0.46 \mathrm{~mm}$, convexity 0.26 $\mathrm{mm}$.

Remarks.-The small size, subquadrate outline, dense pitting and small beak and notch distinguish this species.

Occurrence. - DeQueen Limestone, Gypsum Bluff, near Murpheesboro, Pike County, Arkansas. It has also been recorded from the Lower Cretaceous of Idaho and Wyoming.

\section{Superfamily Cytheracea Baird, 1850}

Family Cytherideidae Sars, 1925

Subfamily Neocy therideinae Puri, 1957

Genus Paracyprideis Klie, 1929

Paracyprideis? graysonensis (Alexander)

Plate 1, Figure 10

Cytheridea graysonensis Alexander, 1929, Univ. Texas Bull. 2907, p. 72, pl. 5, figs. 3, 4.

Haplocytheridea? graysonensis (Alexander) Swain, 1952, U. S. Geol. Survey Prof. Paper 234-B, p. 78, pl. 8, figs. $16,17$.

Paracyprideis graysonensis (Alexander) Howe and Laurencich, 1958, Introd. Study Cretaceous Ostracoda, p. 445, text fig.

The diagnostic features of this shell are the elongate pyriform shape, overlap of right valve by left along all but posterodorsal edges of shell, smooth surface, except for scattered pore canal pits, and low relief of valves. According to Howe and Laurencich the hinge of this species is: in left valve, an anterior smooth socket, behind which is a bar that extends back along middle of hinge line, and in right valve the sharp valve edge projects farther at ends of hinge than in the middle.

Length of a figured specimen (Pl. 1, Fig. 10) $0.70 \mathrm{~mm}$, height $0.40 \mathrm{~mm}$, convexity $0.32 \mathrm{~mm}$.

Remarks.-The writers are not completely satisfied with the generic assignment of the specimens included in this species. Until the internal structures are better known, particularly the hingement and inner lamellae of the southeastern United States specimens, the assignment to Paracyprideis is tentative.

Occurrence.-Rare in lower member of Atkinson Formation, Humble Oil and Refining Company's No. 1 Bennett and Langdale well, core sample 3,690-3,700 and 3,700-3,710 feet; Sun Oil Company's Tillis No. 1 well, Suwannee County, Florida, core sample 3,240-3,250 feet; Sun Oil Company's No. 1 Johnson well, Columbia County,
Florida, core sample 2,955-2,965 feet; Sun Oil Company's No. 1 Westbury well, Putnam County, Florida, core sample 3,834-3,838 feet. The species was described from the Grayson Formation of northeastern Texas and has also been recorded from the subsurface of North Carolina in beds of Eagle Ford and older Cretaceous age.

\section{Subfamily Cytherideinae Sars, 1925}

Genus Fossocytheridea Swain and Brown, n. gen.

Shell medium size, dimorphic; females subovate in side view; males subelliptical; dorsum moderately to strongly convex, umbonate in females, venter nearly straight in left valve. Valves moderately convex in males, strongly convex in females. Valves distinctly unequal in size, left larger, overlapping and extending beyond right around all but the posterior margin.

Hinge margin of right valve consists of an anterior elongate denticulate toothlike area, an interterminal depressed crenulate section, and a posterior denticulate tooth shorter than anterior toothlike section. Muscle scar a submedian vertical row of four spots and two additional more anterior spots. Inner lamellae rather narrow, broadest anteriorly; line of concrescence and inner margin nearly coincide. Radial canals fairly numerous, about 25 anteriorly, less numerous posteriorly and sparse ventrally; anteriorly, canals are expanded medially and in part occur in pairs. Normal canals fairly numerous.

Hinge of left valve comprises terminal denticulate socket-grooves and an interterminal high bar, along the crest of which lies a weak crenulate furrow; dorsal to bar is a distinct accommodation groove.

Free margins of left and right valves provided with well developed selvage groove and flange respectively.

A rather narrow, shallow to deep, slightly curved sulcus arises near anterior margin about one-half from anterior end and extends ventrally to near midheight. General surface smooth to weakly pitted.

Type species, F. lenoirensis Swain and Brown, n. sp.; geologic range, Lower Cretaceous.

Discussion.-The new genus is similar in general shape to Ovocytheridea Grekoff and Dolocytheridea Triebel, but differs from both in having an antero-median sulcus, and in details of hingement. It closely resembles Cyprideis Jones in shape and hingement and in pronounced dimorph- 

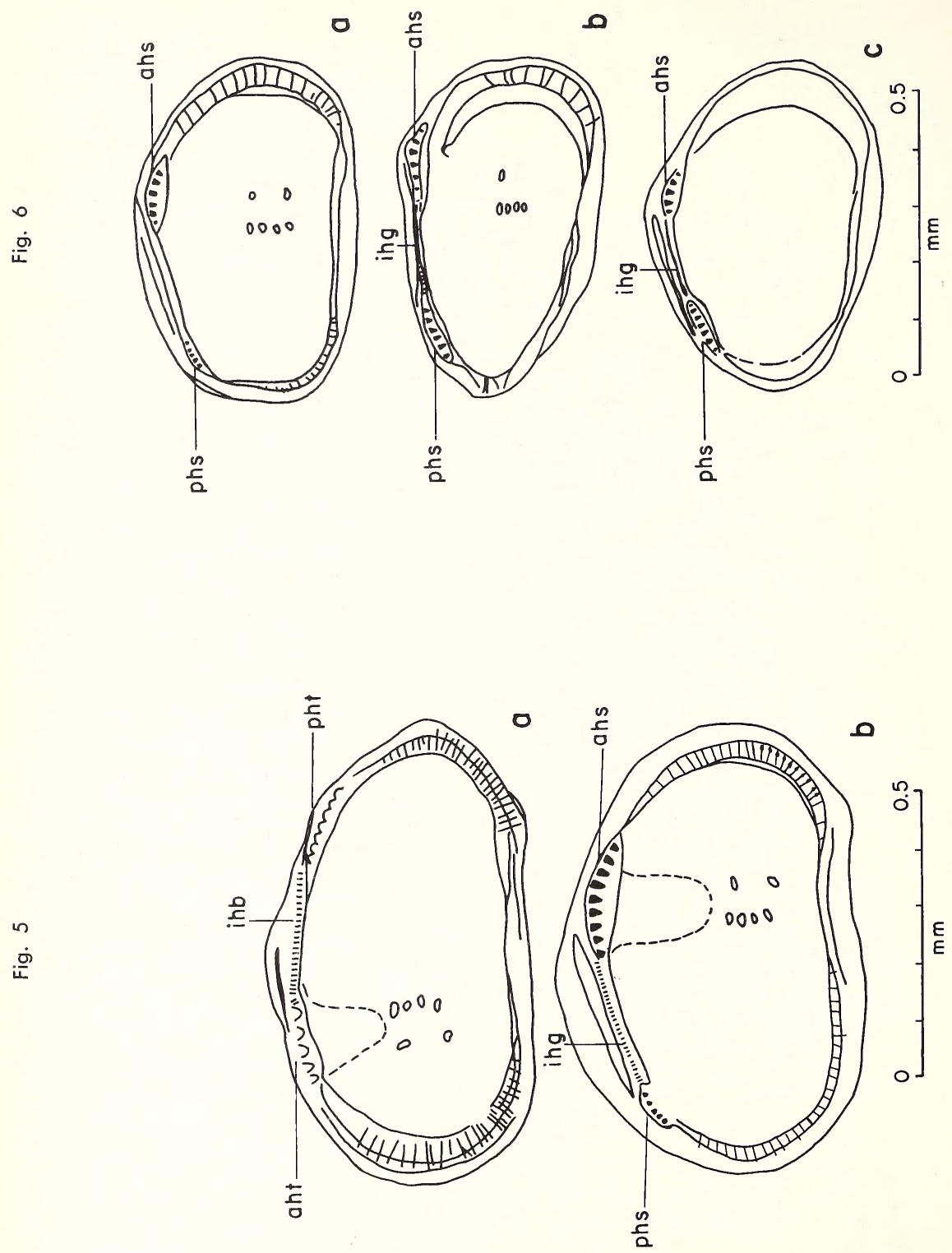
5a,b. Fossocytheridea lenoirensis Swain and Brown, n. gen., n. sp., interior views of right and left valve paratypes respectively, beds of Washita age, DuPont water well No. 6 , Lenoir County, North Carolina, 723-826 feet

Figure 6.

6a. Clithrocytheridea halifaxensis Swain and Brown, n. sp., interior of holotype left valve, beds of Washita age, Caledonia Prison Farm water well T-4, Halifax County, North Carolina, 151-156 feet

6b. Perissocytheridea odomensis Swain and Brown, n. sp., interior of paratype left valve, beds of Washita age, Caledonia Prison Farm water well T-2, Halifax County, North Carolina, 191-196 feet

6c. Schuleridea washitaensis (Alexander), interior of a left valve, lower member of Atkinson Formation, Humble Oil and Refining Company's No. 1 Bennett and Langdale well, Echols County, Georgia, 3,700-3,710 feet 
ism, and that genus also may be weakly sulcate; the sulcus in Cyprideis, however, is more medially located and generally broader and shallower than in Fossocytheridea. The new genus, like Cyprideis, probably represents lagoonal or brackishwater environments.

\section{Fossocytheridea lenoirensis Swain and Brown, n. sp.}

Plate 1, Figures 11a-h; Plate 2, Figures la-j, 2

Text Figures 5a, b

Shell of mature female subovate in side view, highest medially; dorsal margin of left valve strongly convex, umbonate, with somewhat steeper anterior than posterior slope; dorsal margin of right valve moderately convex, truncate along its posterior slope. Ventral margin of left valve nearly straight, curving more abruptly into anterior than into posterior margin; ventral margin of right valve concave, slightly sinuous anteriorly. Anterior margin of left valve broadly rounded, slightly extended below; posterior margin somewhat more broadly rounded and slightly extended medially. Valves strongly convex, with greatest convexity occurring about one-third from posterior end. Left valve larger than and extending strongly beyond right, except posteromedially.

Surface of right valve bears an anterodorsal narrow, fairly deep sulcus that extends ventrally from a position near dorsal margin, about onethird from anterior end, to a little dorsal to midheight where it gradually dies out. Some mature specimens have low broad nodes in front of and behind sulcus and an additional one or two faint nodes in posterior third of valve. Surface, posterior to sulcus, markedly swollen. Corresponding sulcus on left valve is shorter and more pitlike, and nodes are less commonly present. Posterior portion of right valve slightly compressed and its margin bears a short median flangelike extension that results in little or no posterior overreach of right valve by left. General surface in well preserved specimens marked by rather large, widely spaced shallow pits.

Hinge of left valve composed of a slightly antero-median, elongate, socket depression containing about eight cross-ridges, an interterminal high bar formed of the fusion of two shell laminae that in turn separate to define the terminal sockets; crest of bar has a very shallow, weakly crenulate groove, and a posterior shorter, denticulate depression containing six to eight cross-ridges. Hinge of right valve has terminal elevated denti- culate areas, in the posterior of which the crossridges have double crenulations or, expressed differently, the cross-grooves are alternately shallower and deeper; and an interterminal crenulate depressed portion. Muscle scar an anteromedian vertical row of four spots with an additional two spots lying in front of upper and lower ends of main row; inner lamellae narrow, broadest anteriorly; only a narrow vestibule terminally. Radial canals number about 25 anteriorly and tend to occur in pairs, one above the other; some of canals have median expansions; canals are fewer in number posteriorly and scarce ventrally. Normal canals vary from fairly numerous to sparse; they apparently do not necessarily correspond in position to surface pits.

Shell of mature male subelliptical in side view, left valve much less umbonate than in female and right valve is somewhat more elongate than in corresponding female shell. Convexity of male shell much less than that of female. Other shell features of the dimorphs are the same.

Immature molts are characterized by more triangular outline, weaker dentition and other marginal features and more prominent nodes on surface of valves.

Length of holotype, a female left valve, 0.88 $\mathrm{mm}$, height $0.56 \mathrm{~mm}$, convexity of valve $0.30 \mathrm{~mm}$; length of paratype male shell $0.82 \mathrm{~mm}$, height $0.46 \mathrm{~mm}$, convexity $0.36 \mathrm{~mm}$.

Relationships.-The new species somewhat resembles Cyprideis littoralis Brady (1869) in general shape, convexity and presence of a sulcus. The sulcus in $C$. littoralis however is more nearly median in position and is broader and shallower than in $F$. lenoirensis. The latter also is much more umbonate in the left valve than $C$. littoralis.

Occurrence.-Rare to abundant in beds of probable Washita (Albian) age, subsurface of northeastern North Carolina. It has been found in the following wells; DuPont water well No. 6, Lenoir County, 723 feet and below; Greenville city water well, Pitt County, 608 feet and below; Caledonia Prison Farm water well No. T-2, Halifax County, 271 feet and below; Caledonia Prison Farm water well No. T-4, 141 feet and below; Scotland Neck water well No. T-1, Halifax County, 271 feet and below; Scotland Neck water well No. T-2, 270 feet and below; Scotland Neck water well No. T-3, 278.6 feet and below; Odom water well No. T-1, Northampton County, 108 feet and below; Odom water well No. T-3, 185 feet and below. 
Genus Haplocy theridea Stephenson, 1936

\section{Haplocy theridea multiclef ta Swain and Brown, n. sp.}

Plate 2, Figure 4

Shell subquadrate to subelliptical in side view, greatest height a little posterior to middle; dorsal margin gently convex; ventral margin nearly straight, slightly sinuous owing to small anterior concavity; anterior margin broadly and more or less uniformly rounded; posterior margin more narrowly curved, extended below, subtruncate above. Valves distinctly unequal in size, the left larger, overlapping and extending beyond edge of right along all except anterior margins. Valves moderately convex, rising rather abruptly from margins as seen in edge view, general surface of right valve more or less flattened, that of left valve more convex.

Each valve has a narrow, anteromedian sinuous furrow that extends from near dorsal margin to slightly ventral to midheight, a low swelling occurs anterior to furrow; left valve with a small dorso-median submarginal elevation; subventral furrows lie anterior and posterior to main anteromedian furrow; bottom of these auxiliary furrows pitted.

Hinge of left valve consists of an anterior denticulate socket containing about seven cross denticles, an interterminal very finely crenulate groove and a posterior denticulate socket that has five or six cross bars ; hinge of right valve, correspondingly, bears terminal denticulate toothlike elevations and a crenulate bar. Inner lamellae narrow, line of concrescence and inner margin slightly separated anteriorly; radial canals short and number about 20 anteriorly, not clearly seen along other margins; normal canals numerous, more or less arranged in vertical rows corresponding to small surface pits. Muscle scars not observed.

Length of holotype shell $0.63 \mathrm{~mm}$, height 0.38 $\mathrm{mm}$, convexity $0.30 \mathrm{~mm}$.

Relationships.- The hingement and other general shell characteristics ally this species to Haplocytheridea, although the elliptical form is somewhat atypical. The form of the shell is close to Cytheridea amygdaloidea (Cornuel) Alexander (1929, p. 69) (?=Dolocytheridea by Howe and Laurencich, 1958, p. 273), but the pitted grooves on the surface of the present species are distin- guishing features. J. H. Neale (personal communication) has pointed out the close similarity of our species to Cyamocytheridea Oertli in oval shape and hingement. That genus, however, is described as having a distinct anterior vestibule, a feature which is only weakly developed in our species.

Occurrence.-Rare in Lower Cretaceous, probably of Washita (Albian) age, DuPont water well No. 6, Lenoir County, North Carolina, 733-743 feet.

Haplocytheridea lunarea Swain and Brown, n. sp.

Plate 2, Figures 3a, b

Haplocytheridea? sp. aff. $H$ ? plummeri (Alexander) Swain, 1952, U. S. Geol. Survey Prof. Paper 234-B, p. 79, pl. 8, fig. 15.

The external features of the specimens from the Hatteras Light well were described in detail by Swain and the present specimens appear to be the same species. The diagnostic characteristics are the subpolygonal outline, angulated dorsomedian and posterodorsal margin, spinose anterior margin, and distinct widely spaced, mediumsize surface pits.

Length of holotype shell $0.73 \mathrm{~mm}$, height 0.46 $\mathrm{mm}$, convexity $0.37 \mathrm{~mm}$.

Relationships-The outline of this species is similar to that of $H$. ? bruceclarki (Israelsky) (1929, p. 11) of the Marlbrook Marl of Arkansas and to other species of the Upper Cretaceous, but lacks well defined subvertical rows of median pits in small furrows that characterize those species. H. ? punctura Schmidt (1948, p. 425) of the Upper Cretaceous of Delaware is similar in general shape and surface ornamentation but is more triangular and with less angulated posterodorsal margin and more pointed posterior end than the present species.

Occurrence.-Rare in deposits cited as of Eagle Ford (upper part of Atkinson) age by P. L. and E. Applin (written communication) in Coastal Petroleum Company's No. 1 Larsh well, Jefferson County, Florida, core 3,445-3,451 feet; also in beds of Black Creek (?) and Eutaw (?) or Austin age, Esso Standard Oil Company's No. 1 Hatteras Light well, in drill cuttings from 3,550-3,560 feet and below. 
Genus Clithrocytheridea Stephenson, 1936

Clithrocytheridea halifaxensis Swain and Brown, n. sp.

Plate 2, Figures 5a-c

Text Figure 6a

Shell subovate in side view, highest anterior to middle; dorsal margin moderately convex, sloping more steeply in front of than behind position of greatest height; ventral margin gently convex; anterior margin broadly and uniformly rounded; posterior margin more narrowly rounded, extended below especially in right valve, subtruncate above. Left valve larger than right; complete carapace not seen, but judged from the selvage, left valve overlaps and extends beyond edge of right, except posteroventrally.

A shallow anteromedian sulcus extends from near dorsal margin to midheight; surface posterior to sulcus is inflated in both valves, and in right valve a low elevation of surface occurs anterior to sulcus. Surface of valves, except for smooth marginal zone, is coarsely and densely pitted.

Hinge of left valve consists of an elongate denticulate socket containing about six cross-bars, an interterminal weakly crenulate bar dorsal to which is an accommodation groove, and a posterior, somewhat smaller and narrower, denticulate socket. Hinge of right valve has denticulate terminal sockets, between which the interterminal area is depressed, faintly grooved, and has a very weak accommodation groove. Inner lamellae not broad, line of concrescence and inner margin separated anteriorly and posteriorly; radical canals number about 12 anteriorly, fewer posteriorly, and are irregularly spaced. Muscle scar a somewhat anteromedian vertical row of four spots and two additional spots anterior to ends of main row.

Length of holotype left valve $0.65 \mathrm{~mm}$, height $0.40 \mathrm{~mm}$, convexity of valve $0.20 \mathrm{~mm}$.

Relationships.-The new species is generally similar to the Eocene C. garretti (Howe and Chambers) (1935, p. 14) in shape, hingement and surface pitting. It is more ovate and less triangular than $C$. garretti and is considerably more ovate and with much coarser surface pitting than other described Cretaceous species. Clithrocytheridea decumana Triebel $(1938$, p. 492$)$ from the Aptian of Germany resembles the new species in general shape and coarsely pitted surface, but is more pointed posteriorly and has a small posteroventral spine.

Occurrence.-The species is rare in the lower
Cretaceous in the Caledonia Prison Farm water well T-2, Halifax County, North Carolina, from depths of 166-176 feet and 241-246 feet; and in the T-4 water well from 151-156 feet; probably Washita (Albian) in age.

Genus Dolocytheridea Triebel, 1938

Dolocytheridea? caledonensis Swain and Brown, n. sp.

Plate 2, Figure 6

Shell elongate, almond-shaped in side view, highest medially, dorsal margin moderately and nearly uniformly convex; ventral margin gently convex, slightly sinuous anteriorly; anterior margin broadly curved, slightly extended below; posterior margin more narrowly rounded, extended medially. Left valve appreciably larger than right, overlapping and extending beyond right strongly along dorsal and ventral, but less strongly along terminal margins. Valves rather strongly convex, with greatest convexity posteromedian in position. Surface nearly smooth, except for a few scattered pits.

Hinge of right valve consists of terminal denticulate and elongate toothlike elevations and an interterminal faintly crenulate groove; hinge of left valve, correspondingly, is made up of denticulate terminal sockets and an interterminal crenulate bar. Muscle scars an anteromedian vertical row of four spots and two more anterior spots lying opposite each end of main group.

Inner lamellae of moderate width; line of concrescence and inner margin separated terminally; radial canals numerous, occupying different levels along marginal zone and emerging at different horizons along outer margin. Normal canals numierous, widely but uniformly spaced.

Length of holotype shell $0.73 \mathrm{~mm}$, height 0.43 $\mathrm{mm}$, convexity $0.37 \mathrm{~mm}$.

Relationships.-This species is very closely similar to. "Cytheridea amygdaloides" Alexander (1929, p. 69) from the Kiamichi of Texas which according to Howe and Laurencich (1958, p. 273) is not Cythere amygdaloides (Cornuel) $(=$ Dolocytheridea hilseana (Roemer) ) but is probably a Dolocytheridea. Alexander's species is not as elongate as the present form and is here considered a separate species.

Occurrence.-Rare in Caledonia Prison Farm water well T-4, Halifax County, North Carolina, Lower Cretaceous of early ? Albian (late Fredericksburg) age. 
Genus Perissocytheridea Stephenson, 1936

Perissocytheridea odomensis Swain and Brown, n. sp.

Plate 2, Figures 7, 8a, b

Text Figure 6b

Shell subquadrate-acuminate in side view, highest about one-fifth from anterior end; dorsal margin nearly straight, about three-fifths of shell length, with well defined obtuse cardinal angles, the posterior angle larger than the anterior; ventral margin gently convex; anterior margin broadly rounded, slightly extended below; posterior margin acuminately curved, strongly extended medially, concave above. Left valve a little larger than right, overlapping and extending beyond right anteriorly and posterodorsally. Valves strongly convex, greatest inflation posteromedian. Terminal marginal zones compressed.

Anterodorsal portion of each valve depressed as a broad sulcus which extends only to midheight; a large pointed node and dorsally-adjacent eye tubercle define sulcus anteriorly; posterior to sulcus, surface strongly swollen as a node or lobe which medially extends beyond dorsal margin; ventral portion of valve bears a series of three nodes arranged as a subalate ridge; general surface coarsely but weakly reticulate; flattened ventral surface bears about four low, narrow, longitudinal ridges.

Immature specimens are characterized by more strongly reticulate and ridged surface ornamentation, but also have the dorsal nodes and sulcus more weakly developed and have little or no development of the ventral nodose ridge.

Hinge of left valve consists of terminal very elongate denticulate sockets that taper gradually to extinction in direction of rather short interterminal, weakly crenulate bar formed by edge of valve. Muscle scar a small subvertical anteromedian row of four spots plus two additional, considerably more anterior spots. Inner lamellae of moderate width, vestibules developed terminally; radial canals rather few and widely spaced, about ten anteriorly and five posteriorly, and with additional canals ventrally. Normal canals few and widely spaced.

Length of holotype $0.77 \mathrm{~mm}$, height $0.38 \mathrm{~mm}$, convexity excluding nodes $0.33 \mathrm{~mm}$, convexity including nodes $0.45 \mathrm{~mm}$.

Relationships.- The shape, sulcation and lobation and internal structures of this species relate it to Perissocytheridea. The pattern of surface nodes serves to distinguish this species from other described forms. This genus is characteristic of lagoonal and estuarine conditions in which salinity varies from brackish to hypersaline.

Occurrence.-Lower Cretaceous, probably of Washita (Albian) age, of the subsurface of northeastern North Carolina; Odom water well T-1, Northampton County, 190-200 feet; Caledonia Prison Farm water well T-2, Halifax County, 191196 feet, and T-4 well, 141-146 feet.

Genus Schuleridea Swartz and Swain, 1946

Schuleridea washitaensis (Alexander)

Plate 2, Figures 9a-e; Text Figure 6c

Cytheridea washitaensis Alexander, 1929, Univ. Texas Bull. 2907, p. 71, pl. 4, figs. 12, 14.

Calahan, 1939, Shreveport Geol. Soc. Guidebook 14th Annual Field Trip, p. 45, pl. 5, figs. 9, 10.

Schuleridea washitaensis (Alexander). Howe and Laurencich, 1958, Introd. Study Cretaceous Ostracoda, p. 494, text fig.

Shell subtriangular-subpyriform in side view, highest about two-fifths from anterior end; dorsal margin strongly convex, subangulate at position of greatest height, sloping more steeply in front of than behind position of greatest height; ventral margin nearly straight in right valve, gently convex in left; anterior margin broadiy curved, extended medially; posterior margin narrowly rounded, subacuminately extended below. Left valve larger than right (although reversal has been noticed), extending beyond edge of right on all except posterodorsal margin. Valves of moderate tumidity, greatest convexity median in position. Just anterior to apex of dorsum, right valve bears a small oblique tubercle, presumably the eye spot, and anteriorly-subjacent weak furrow. Anterior margin, and to a lesser extent posterior margin, of right valve bears a narrow thickened lip. General surface of midportion of valves has small, widely spaced pits.

Hinge of left valve consists of elongate, terminal, finely denticulate sockets and an interterminal, very weakly crenulate furrow, dorsal to which is an accommodation groove; hinge of right valve has terminal, denticulate, elongate, elevated dental areas and an interterminal crenulate bar. Inner lamellae fairly broad terminally; line of concrescence and inner margin nearly coincide. Musculature and pore canals not observed. 
$\infty$
모
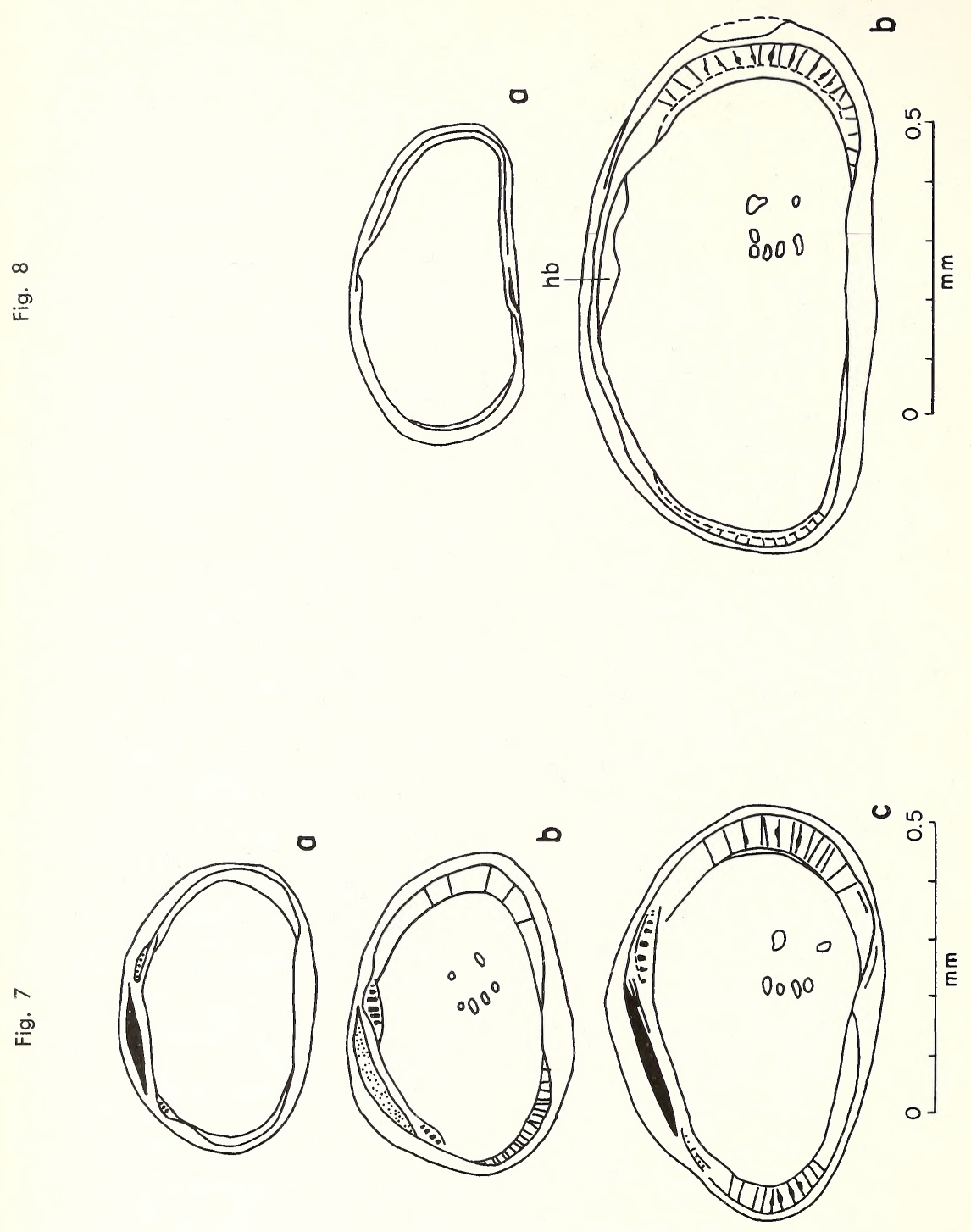
7a. Asciocythere rotunda (Vanderpool), interior of paratype immature left valve, Glen Rose Formation, eight miles west of Weatherford, Texas

7b. Asciocythere rotunda (Vanderpool), interior of holotype left valve, Glen Rose Formation, eight miles west of Weatherford, Texas

7e. Asciocythere perforata (Vanderpool), interior of paratype left valve, Glen Rose Formation, eight miles west of Weatherford, Texas

Figure 8.

8a. Eucytheroides pustulosa (Swain), interior of a right valve, beds of Washita age, Odom Townsite water well no. T-1, Northampton County, North Carolina, 185-190 feet

8b. Eucythere semiglypta Swain and Brown, n. sp., beds of Fredericksburg (?) and Washita age, Caledonia Prison Farm water well no. T-2, Halifax County, North Carolina, 191-196 feet 
Length of figured specimen (Pl. 2, Fig. 9b) 0.63 $\mathrm{mm}$, height $0.41 \mathrm{~mm}$, convexity $0.28 \mathrm{~mm}$.

Remarks.-The subtriangular shape together with eye tubercles, overlap relationships and weak surface pitting ally the present specimens with those described by Alexander (1929, p. 71) from the Grayson Shale (upper Albian) of northeastern Texas.

Occurrence.-Rare in the lower member of Atkinson Formation, Humble Oil and Refining Company's No. 1 Bennett and Langdale well, Echols County, Georgia, core sample 3,700-3,710 feet. The species was originally described from the Grayson Shale of Texas.

\section{Schuleridea dorsoventrus (Vanderpool)}

Plate 4, Figures 6a-c, 7a, b

Bairdia dorsoventrus Vanderpool, 1928, Jour. Paleont., v. 2, p. 98, pl. 13, figs. 3, 4 .

Howe and Laurencich, 1958, Introd. Study Cretaceous Ostracoda, p. 69, text fig.

Bairdia glenrosensis Vanderpool, 1928, Jour. Paleont., v. 2, p. 100, pl. 13, figs. 1, 2 .

Howe and Laurencich, 1958, Introd. Study Cretaceous Ostracoda, p. 70, text fig.

Shell subovate to subtriangular in side view, highest slightly anterior to middle; dorsal margin strongly convex, subangulated medially, truncated behind position of greatest height; ventral margin gently convex to nearly straight; anterior margin broadly and nearly uniformly rounded, slightly extended below; posterior margin narrowly and subacuminately curved, strongly extended below, truncate above; the above features of outline apply to larger left valve; outline of right valve is straightened mid-dorsally, and slightly sinuous ventrally. Left valve larger than right, overlapping around entire periphery and over-reaching right strongly along dorsum and venter. Valves not strongly convex, terminal areas slightly compressed, posteromedian portion of shell somewhat swollen.

An oblique anterodorsal swelling, presumably the eye tubercle, is defined on its ventral side by a shallow oblique furrow. General surface of valves smooth.

Hinge structure, as viewed by transmitted light, consists of terminal, crenulate, elongate sockets in left valve and intervening hinge area that could not be observed clearly but dorsal to which, in left valve, is a prominent accommodation groove. Muscle scar not seen. Radial canals numerous and closely spaced terminally as seen in transmitted light, fewer and widely spaced dorsally and ventrally; inner lamellae fairly broad, line of concrescence and inner margin nearly coincide.

Length of holotype (Pl. 4, Fig. 6a) $0.87 \mathrm{~mm}$, height $0.60 \mathrm{~mm}$, convexity $0.37 \mathrm{~mm}$.

Remarks.- The hingement and marginal features as well as the general form of the shell ally this species with Schuleridea rather than with Bairdia. S. hatterasensis Swain (1952, p. 74) from the subsurface Lower Cretaceous of North Carolina is similar in shape to $S$. dorsoventrus but has a densely pitted surface.

The forms described as Bairdia glenrosensis Vanderpool are apparently immature molts of dorsoventrus, the latter name having page priority over glenrosensis.

Occurrence.-Common in the Glen Rose and DeQueen Formations at localities in northeastern Texas, southern Arkansas, and northwestern Louisiana according to Vanderpool (1928, p. 100).

Genus Asciocythere Swain, 1952

Asciocythere rotunda (Vanderpool)

Plate 4, Figures 3a-d, 4a-c

Text Figures 7a, b

Bythocypris rotundus Vanderpool, 1928, Jour. Paleont., v. 2, p. 102, pl. 13, figs. 5, 6.

? Cytheridea amygdaloides brevis Alexander, 1929, (not Cornuel), Univ. Texas Bull. 2907, p. 70 , pl. 4 , fig. 13 .

Cytheridea rotundus (Vanderpool). Vanderpool, 1933, Jour. Paleont., v. 7, p. 411.

? Cytheridea amygdaloides brevis Calahan, 1939, (not Cornuel), Shreveport Geol. Soc. Guidebook 14th Annual Field Trip, p. 49, pl. 7, fig. 11. not Haplocytheridea? amygdaloides brevis Schmidt, 1948, Jour. Paleont., v. 22, p. 426, pl. 62, figs. 20-22.

Asciocythere rotunda (Vanderpool). Swain, 1952,

U. S. Geol. Survey Prof. Paper 234-B, p. 76, pl. 8, figs. 22-23.

Howe and Laurencich, 1958, Introd. Study Cretaceous Ostracoda, p. 61-62, text fig.

The shell of the species was described earlier (Swain, 1952, p. 76). The specimens illustrated here are Vanderpool's types from the Glen Rose Formation about eight miles west of Weatherford, Parker County, Texas, from northwestern Louisi- 
ana and from the DeQueen Limestone at Gypsum Bluff and Messers Creek, Arkansas.

Length of holotype left valve $0.60 \mathrm{~mm}$, height $0.42 \mathrm{~mm}$, convexity of valve $0.20 \mathrm{~mm}$.

Occurrence.-DeQueen and Glen Rose Formations of southern Arkansas, northwestern Louisiana, and northeastern Texas; beds of Trinity (?) and pre-Trinity (?) age, subsurface of North Carolina; beds of Trinity age in southern Oklahoma and in the Kiamichi Formation (Fredericksburg Group) of northeastern Texas. The holotype is from the Glen Rose Formation, about eight miles west of Weatherford, Parker County, Texas.

\section{Asciocy there perforata (Vanderpool)}

Plate 4, Figures 5a-f; Text Figure 7c

Pontocypris perforata Vanderpool, 1928, Jour.

Paleont., v. 2, p. 102, pl. 14, figs. 9, 10.

Howe and Laurencich, 1958, Introd. Study Cretaceous Ostracoda, p. 465, not text figure, which is a copy of Vanderpool's Cypridea. tuberculata var. gypsumensis (1928, pl. 13, fig. 10).

Shell features are as described earlier. The hinge not previously described is as follows: in left valve, hinge consists of an anterior short crenulate socket, an interterminal weakly crenulate bar and a posterior crenulate socket; dorsal to median portion of hinge is a prominent accommodation groove. Muscle scar a submedian vertical row of four spots and two additional more anterior spots. Inner lamellae moderately broad; line of concrescence and inner margin slightly separated. Radial canals numerous both terminally and ventrally and in part have median bulbous expansions. Ventral margin with prominent selvage apophysis.

Length of lectotype (Pl. 4, Fig. 5a) $0.85 \mathrm{~mm}$, height $0.50 \mathrm{~mm}$, convexity $0.43 \mathrm{~mm}$.

Remarks.-The hingement of the species is that prescribed for Asciocythere, although the general shape and posteroventral spinose extension are like Haplocytheridea.

Occurrence.-Reported by Vanderpool to occur commonly in the Glen Rose Formation of northeastern Texas and northern Louisiana and less commonly in the DeQueen Limestone of southern Arkansas. An externally closely similar though not identical form was found in the Black Creek and Eutaw equivalents of the North Carolina sub- surface (Swain, 1952, p. 79). That species is here referred to Haplocytheridea lunarea Swain and Brown, n. sp.

\section{Subfamily Eucy therinae Puri, 1954}

Genus Eucy there Brady, 1868

Eucythere semiglypta Swain and Brown, n. sp.

Plate 2, Figures 10a-f; Plate 3, Figures 1a, b

Text Figure $8 \mathrm{~b}$

Shell elongate-subreniform to subtriangularacuminate; dorsal margin moderately convex, slightly angulate at position of greatest height with steeper posterior than anterior slope; ventral margin nearly straight, slightly concave medially in right valve; anterior margin broadly and uniformly curved; posterior margin narrowly rounded and strongly extended to subacuminate below; posteroventral submarginal bend of right valve in part with a short spinose extension. Left valve larger than right, overlapping and extending beyond the other around entire periphery. Valves moderately convex, with greatest expansion in posterior third.

Ornamentation consists principally of irregular closely spaced grooves in posterior third; grooves are branching and anastomosing, longitudinally arranged in ventral part, and sweeping upward in dorsal part of valve; grooved surface appears irregularly nodose; anterior half of shell varies from smooth to weakly pitted, and with low, irregular, roughly-longitudinal ridges in some specimens.

Hinge of right valve formed of the ridgelike extension of dorsal edge of valve which fits into corresponding groove in edge of anterior half of left valve; at position of greatest height, right valve ridge is interrupted by a small notch. Hinge of left valve consists, in anterior half, of a groove for reception of edge of right; ventrad of groove, beginning at midlength and extending to about one-fourth from anterior end, is a strong ridge process which has a blunt anterior termination. Posterior to position of greatest height, hinge edge of left valve fits over edge of right without further articulation.

Muscle scar consists of an anteromedian vertical, slightly curved row of four closely spaced spots and two additional spots lying anterior to the upper and lower ends of main group; upper of the two spots horseshoe-shaped or double. Inner lamellae moderately broad anteriorly, nar- 
rower elsewhere; line of concrescence and inner margin separated to form a fairly wide vestibule anteriorly. Radial canals number about 20 anteriorly, about ten posteriorly and a few occur along ventral and dorsal margins; anteromedially, they occur in pairs. Normal canals widely spaced.

Length of holotype left valve $0.95 \mathrm{~mm}$, height $0.50 \mathrm{~mm}$, convexity of valve $0.26 \mathrm{~mm}$; length of paratype immature but complete shell $0.70 \mathrm{~mm}$, height $0.43 \mathrm{~mm}$, convexity $0.35 \mathrm{~mm}$.

Relationships. - The elongate subreniform, rather than subtriangular, outline of the species appears only in large shells. It is uncertain whether this is a dimorphic feature, characteristic of females or is the mature stage of all specimens. Among described species $E$. solitaria Triebel (1940, p. 162) from the Albian of Germany is close to the subtriangular forms of the present species, but is smooth-surfaced.

Occurrence.-Rare to frequent in Lower Cretaceous deposits of probable Washita (Albian) age, subsurface, of northeastern North Carolina in following wells: Greenville City water well, Pitt County, 608 feet and below; Odom water well No. T-1, Northampton County 185-190 feet; Caledonia Prison Farm water well No. T-2, Halifax County 151-196 feet; Caledonia Prison Farm water well No. T-4, 161-246 feet. The sample in the T-4 well from 241-246 feet has other fossils that suggest a Fredericksburg age.

Genus Eucytheroides Swain and Brown, n. gen.

Leguminocythereis? Swain, 1948. Maryland Dept. Geol., Mines and Water Res. Bull. 2, p. 208.

Shell subquadrate, small and bean-shaped, highest anteriorly; dorsal margin nearly straight; anterior margin more broadly curved than posterior margin, the latter extended below. Left valve larger than right, overlapping it. Surface, except smooth marginal zone, pustulose.

Hinge line of right valve contains an anterior long barlike expansion of margin athwart position of greatest height, an interterminal short oblique furrow, and a posterior barlike ridge also formed of valve edge; the interterminal groove represents a zone lying between the two, slightly en echelon, edges of the terminal bars. Inner lamellae narrow, vestibule present; radial canals widely spaced. Muscle scar an anteromedian vertical row of four spots and other more anterior spots.

Type species, Leguminocythereis? pustulosa
Swain. Geologic range, upper part of Lower Cretaceous, Albian Stage.

Relationships.-The general form and hingement are close to Eucythere Brady, but the new genus is more quadrate in outline and has markedly pustulose surface ornamentation as compared to the smooth or pitted surface of Eucythere.

\section{Eucy theroides pustulosa (Swain)}

Plate 3, Figure 2; Text Figure 8a

Leguminocythereis? pustulosa Swain, 1948, Maryland Dept. Geol., Mines and Water Res. Bull. 2, p. 208, pl. 14, fig. 11 .

Howe and Laurencich, 1958, Introd. Study Cretaceous Ostracoda, p. 378, text fig.

The shell characteristics of this species were given in the original description. The hinge of the right valve is described above. The single specimen from North Carolina appears identical to that from the subsurface of Maryland.

Length of figured right valve $0.58 \mathrm{~mm}$, height $0.30 \mathrm{~mm}$, convexity of valve $0.15 \mathrm{~mm}$.

Occurrence.-Lower Cretaceous, probably of Washita (Albian) age, Odom water well T-1, Northampton County, North Carolina, 185-190 feet. The species was originally described from the Ohio's Hammond No. 1 well, Wicomico County, Maryland in core sample from depths of 1,5881,598 feet in what was at that time suggested to be the Raritan Formation (Anderson and others, 1948 , p. 16), but which is probably Lower Cretaceous.

\section{Family Brachycytheridae Puri, 1954}

Genus Brachycythere Alexander, 1933

\section{Brachycythere nausif ormis Swain}

Plate 3, Figures 3a-c

Brachycythere nausiformis Swain, 1952, U. S. Geol. Survey Prof. Paper 234-B, p. 80, pl. 8, figs. 44-47.

Brown, 1957, North Carolina Dept. Cons. and Devel. Bull. 70, p. 12, pl. 4, figs. 3, 4 .

Howe and Laurencich, 1958, Introd. Study Cretaceous Ostracoda, p. 88, text fig.

The external characteristics and musculature of the species were described previously (Swain, 1952, p. 80) ; the hingement has not been observed clearly, because of lack of separated valves. The present specimens from Alabama have the pyri- 
form shape, broad midventral ridge and dorsojacent furrow, and the deeply pitted surface characteristic of the species.

Length of a figured specimen (Pl. 3, Fig. 3a) $0.65 \mathrm{~mm}$, height $0.40 \mathrm{~mm}$, convexity $0.38 \mathrm{~mm}$.

Occurrence.-Rare in beds cited as Eagle Ford (upper member of Atkinson) in age by P. L. and E. Applin (written communication) from Escambia Oil Company's State Line Land and Lumber No. 1 well, Escambia County, Alabama, core sample 4,679-4,684 feet.

Genus Alatacythere Murray and Hussey, 1942

\section{Alatacy there tokiana (Israelsky)?}

Plate 3, Figure 4

Cytheropteron tokiana Israelsky, 1929, Arkansas Geol. Survey Bull. 2, p. 9, pl. 1A, figs. 8, 9a, b.

? Cythereis tokiana Loetterle, 1937, Nebraska Geol. Survey, Second Ser., Bull. 12, p. 55, pl. 9, figs. $4 a, b$.

not Cythereis (Pterigocythereis) tokiana Bold, 1946, Contr. to Study of Ostracoda, DeBussy, Amsterdam, p. 100, pl. 6, fig. 9.

Pterygocythereis cf. P. tokiana Swain, 1952, U. S. Geol. Survey Prof. Paper, 234-B, p. 85, pl. 9, figs. 1-3.

Alatacythere tokiana (Israelsky). Howe and Laurencich, 1958, Introd. Study Cretaceous Ostracoda, p. 45 , text fig.

Shell elongate-subquadrate in side view, highest about one-fourth from anterior end; dorsal margin somewhat sinuous, about three-fourths of shell length and with broadly obtuse cardinal angles; ventral margin gently convex, sinuous due to posteroventral alate expansion; anterior margin broadly curved, extended and bearing three or four short blunt spines below, subtruncate above; posterior margin narrowly rounded, subacuminate and strongly extended medially and bears six or more short spines. Valves more or less compressed, with greatest convexity ventromedian; posterior fifth of valves more strongly compressed than remainder of shell. Left valve slightly larger than right, extending beyond right most strongly in cardinal areas.

Ventral surface of middle two-thirds of each valve strongly expanded as a sharp-crested, backward directed ala. Anterior end provided with a narrow submarginal rim that dorsally begins anterior to rounded eye tubercle and continues ventrally and posteriorly to form narrow crest or ala; posterior margin also bears a narrow rim; posterior to mid-dorsum is a backwardly directed short ridgelike extension that projects beyond dorsal margin; general surface smooth. Internal characteristics not seen in single specimen at hand.

Length of figured shell $0.93 \mathrm{~mm}$, height 0.52 $\mathrm{mm}$, convexity including alae $0.5 \mathrm{~mm}$.

Remarks.-In shape, alation, and submarginal rim structures the present specimen is close to A. tokiana, but perhaps is less pointed posteriorly than is typical for the species; furthermore, the internal characters are not known.

Occurrence.-Beds of Eagle Ford age (upper member of Atkinson Formation), Humble Oil and Refining Company's No. 1 Bennett and Langdale well, Echols County, Georgia, core 3,700-3,710 feet. A similar form was described from beds of Trinity (?) and pre-Trinity age in the Hatteras Light well, Dare County, North Carolina (Swain, 1952, p. 85).

Family Trachyleberidae Sylvester-Bradley, 1948 Genus Cythereis Jones, 1849

Cythereis pittensis Swain and Brown, n. sp.

Plate 3, Figures 7a, b

Shell elongate subquadrate in side view, highest about one-fifth from anterior end; dorsal margin nearly straight, except for irregularity due to dorsal ridge and cardinal angles, about threefourths of shell length, with widely obtuse cardinal angles; ventral margin gently convex, somewhat sinuous due to projecting ventral ridges; anterior margin broadly rounded, somewhat extended below and fringed with about a dozen small short spines; posterior margin narrow, extended, and angulated dorsad of midheight, truncate to slightly concave above, bearing about five short spines below. Left valve slightly larger than right, extending beyond it in cardinal parts of shell. Valves compressed, greatest convexity is posteromedian in position.

Terminal margins of both valves provided with narrow marginal rims; the anterior with knifeedge crest; the posterior is less elevated and bears several of the marginal spines ventrally. Dorsal margin bears a narrow, irregular, sharp-crested ridge which trends from large rounded lucid eye tubercle to posterior cardinal angle; five spurs extend ventrally from inner slope of ridge and in part connect as low ridges with corresponding 
spurs from median ridge. A curved ridge extends ventrally and posteriorly from eye tubercle, a median narrow ridge extends from a position ventrad of eye tubercle, backward and slightly upward, to a point ventral to posterocardinal angle, behind which, posterior end of shell is compressed ; short spurs project at right angles from both flanks of median ridge to join, as low ridges, with spurs from dorsal and inner ventral ridges; two ventral submarginal ridges are slightly shorter than median ridge but are subparallel to it; inner ventral ridge highest posteriorly and joins end of outer ridge with a cross-bar; both ridges die out gradually anteriorly and have several low connecting cross-bars between them. Internal features not observed.

Length of holotype shell $0.56 \mathrm{~mm}$, height 0.30 $\mathrm{mm}$, convexity $0.26 \mathrm{~mm}$.

Relationships.-The species is similar to $C$. worthensis Alexander (1929, p. 92) from the Washita Group of northern Texas in general shape and ornamentation, including the double ventral ridge, but has lower and broader surface ridges. C. quadrialira Swain (1952, p. 84) from beds of Eutaw (?) or Black Creek (?) age of North Carolina also have similar surface ornamentation including two ventral ridges but is more pointed posteriorly and the surface ridges are broader.

Occurrence.-Early Cretaceous, probably of Washita (Albian) age, Greenville City well, Pitt County, North Carolina, composite sample from 608-754 feet.

Cythereis sp. aff. C. glabrella Triebel

Plate 3, Figure 5

Right valve subquadrate in side view; dorsal margin sinuous due to extension of marginal ridge; cardinal angles broadly and gently obtuse, the anterior less wide than the posterior, ventral margin gently convex; anterior margin broadly rounded, somewhat extended below; bearing a few small spines ventrally. Posterior margin acuminate, strongly extended medially, concave above. Valve compressed, most convex posteromedially, posterior fourth strongly compressed.

Anterior margin provided with a narrow, strongly elevated rim that continues uninterrupted along ventral margin but widens posteriorly to a rounded node at place of termination about one-third from posterior end; anteriorly, outer side of rim bears a few small spines, ventral out- er portion has several thick spurs that extend obliquely backward and fuse to form a short subsidiary ridge and enclose a series of curved pits; and inner ventral slope has five or more short spurs projecting from it. Dorsal margin bears a sinuous, rather broad round-crested ridge that extends from lucid eye tubercle to about onefourth from posterior end where it bends slightly toward venter and terminates; posterior margin also provided with a narrow, distinct, but low marginal rim that has several low nodes each of which represents a point of emergence of a radial canal. Median longitudinal ridge broad, consisting of an elongate swollen anteromedian nodelike element and a posterior narrower element separated from the other by a low saddle. Surface between ridges is smooth.

Hinge of right valve consists of an anterior high pointed tooth, notched on its anterior slope and a deep pit anteroventral to it, a posteriorly adjacent deep rounded socket, a long interterminal, very weakly denticulate groove, and a posterior high pointed tooth which has a few weak notches on its anterior side. Free margins of valve bear a narrow selvage ridge, and antero-midventrally a prominent selvage apophysis. Inner lamellae moderately broad, line of concrescence and inner margin coincide; about 12 radial canals anteriorly, and about 7 posteriorly, some are bifurcate outward; also, dorsal and ventral marginal zones each have ten or more radial canals of variable length. Muscle scar consists of a small compact group of four elongate spots lying on anterior slope of inner depression representing anteromedian node, and an additional more anterior spot.

Length of figured right valve $0.65 \mathrm{~mm}$, height $0.33 \mathrm{~mm}$, convexity of valve $0.20 \mathrm{~mm}$.

Remarks.-This shell is similar in shape and general disposition and character of surface ornamentation to the group of Cythereis hawleyi Alexander (1929, p. 95) and C. "nuda" Alexander (1929, p. 91) from the Albian of Texas, but is not pitted as is $C$. hawleyi and has different dorsal and ventral ridges from $C$. "nuda." C. glabrella Triebel (1940) from the Albian of Germany has shape and surface ridges generally like the present species but does not have the short submarginal spurs extending inward as does our form. Veenia paratriplicata (Swain) (1952, p. 85) from the Upper Cretaceous of North Carolina is similar to the present specimens in surface 
ornamentation, but the latter lack the pyriform outline of Veenia. The single right valve at hand is insufficient for the establishment of a new species.

Occurrence.-Early Cretaceous, probably of Washita (Albian) age, of the subsurface of northeastern North Carolina; rare in DuPont No. 6 water well, Lenoir County, composite sample from depth of 723-826 feet.

\section{Cy thereis eaglefordensis Alexander}

Plate 3, Figures 6a-h; Text Figures 9a, b

Cythereis eaglefordensis Alexander, 1929, Univ. Texas Bull. 2907, p. 98, pl. 9, figs. 9, 12.

Howe and Laurencich, 1958, Introd. Study Cretaceous Ostracoda, p. 194, Text fig.

Shell subpyriform to subquadrate in side view; dimorphic, the female shells larger and higher posteriorly than males; shell highest one-fourth to one-fifth from anterior end; dorsal margin markedly sinuous in left valve, nearly straight in right valve; left valve with strong cardinal projection at position of greatest height; cardinal angles obtuse, the posterior broader than anterior, neither is well defined; ventral margin gently sinuous, slightly concave anterad of middle; anterior margin broadly curved, slightly extended ventromedially; posterior margin narrower, rounded and extended below in females, bluntly pointed and extended below in males; ventral two-thirds of anterior margin finely spinose; ventral part of posterior margin bears several thicker blunt spines. Left valve a little larger than right, extending beyond right rather strongly in cardinal areas. Anterior and posterior portions of valves compressed as seen in edge view; midportion wedge-shaped due to subalate expansion of flattened venter; this portion of shell moderately convex; greatest convexity posteromidventral in position.

Anterior marginal zone has narrow-crested spinose rim that dorsally passes into eye tubercle and ventrally dies out near position of greatest height; anteromedially shell surface is raised in a large rounded, low swelling, posterior to which is a low, longitudinal ridgelike elevation; another broad ridgelike expansion occurs midventrally where low blunt alae are developed; anterodorsal surface behind eye tubercle is depressed as an oblique shallow sulcus; posteromid-dorsal surface strongly elevated; general surface coarsely, dense- ly, and deeply pitted in reticulate fashion, diameter of pits about twice width of interspaces.

Hinge of left valve consists of an anterior deep crescent shaped socket which curves around posteriorly adjacent high knoblike tooth, an interterminal crenulate bar and adjoining dorsal furrow, and a posterior deep rounded socket; hinge of left valve has an anterior high notched tooth, posteriorly adjacent socket, interterminal serrate furrow and posterior obliquely rounded high tooth. Inner lamellae of moderate width, line of concrescence and inner margin coincide. Free margin of left valve has a prominent deep selvage furrow and right valve a corresponding selvage ridge.

Length of figured specimen (Pl. 3, Fig. 6a) $0.93 \mathrm{~mm}$, height $0.50 \mathrm{~mm}$, convexity $0.50 \mathrm{~mm}$.

Remarks.-The dimorphism in this species is well developed, and although no dimorphism was described in the Texas specimens, they appear to be conspecific with the present forms.

Occurrence.-The species was obtained from the subsurface lower member of Atkinson Formation of Georgia and Florida in the following wells: (1) Humble Oil and Refining Company's Tindel No. 1 well, Jackson County, Florida, core sample 3,470-3,500 feet, (2) Humble Oil and Refining Company's No. 1 Bennett and Langdale well, Echols County, Georgia, core sample 3,700-3,710 feet, (3) Sun Oil Company's No. 1 Russell well, Suwannee County, Florida, core sample 3,0703,080 feet.

\section{Cythereis quadrialira Swain}

Plate 3, Figures 8a-c

“Archicythereis" ef. Cythereis pidgeoni Berry. Schmidt, 1948, Jour. Paleont., v. 22, p. 417, pl. 62.

Cythereis quadrialira Swain, 1952, U. S. Geol. Survey Prof. Paper 234-B, p. 84, pl. 9, figs. 2730.

Bolin, 1956, Jour. Paleont., v. 30, p. 296, pl. 39, figs. $18 \mathrm{a}-\mathrm{c}$.

Howe and Laurencich, 1958, Introd. Study Cretaceous Ostracoda, p. 227, text fig.

The external characters of the species were described by Swain (1952), while Bolin (1956, p. 296 ), discussed the hingement of his specimen from the Cretaceous of Minnesota, an apparently identical form. Diagnostic characteristics besides shape are the double ridge along the venter, the 

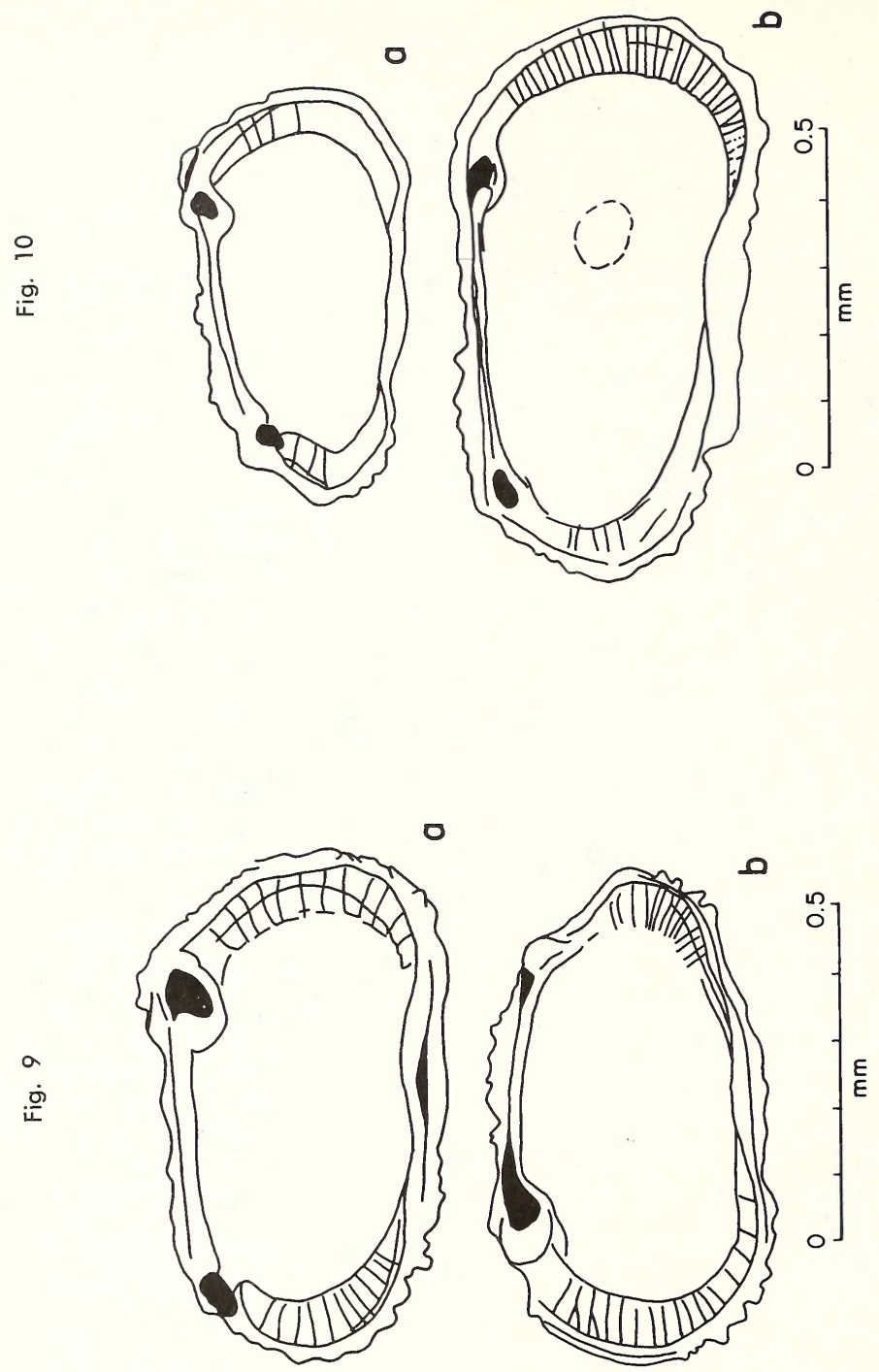
Figure 9.

Page

9a,b. Cythereis eaglefordensis Alexander, interior views of a left and a right valve, lower member of Atkinson Formation, Humble Oil and Refining Company's No. 1 Bennett and Langdale well, Echols County, Georgia, 3,700-3,710 feet

Figure 10.

Page

10a. Cythereis fredericksburgoides Swain and Brown, n. sp., interior of paratype left valve, lower member of Atkinson Formation, Humble Oil and Refining Company's No. 1 Bennett and Langdale well, Echols County, Georgia, 3,700-3,710 feet

10b. Cythereis praeornata Swain and Brown, n. name, interior of holotype left valve, DeQueen Limestone, Gypsum Bluff, Pike County, Arkansas 
shape and spurlike extensions of the upper of the two ventral ridges, together with the median and dorsal longitudinal ridges.

Length of figured specimen $0.65 \mathrm{~mm}$, height $0.33 \mathrm{~mm}$, convexity $0.28 \mathrm{~mm}$.

Remarks.-The generic status of this species remains uncertain, but the hinge described by Bolin (1956, p. 296) is like that in Cythereis. The species belongs in the general group of C. worthensis (Alexander) (1929, p. 92), C.? gapensis (Alexander) (1929, p. 84) and C. pidgeoni (Berry) (1925, p. 425) which have narrow longitudinal ridges from which short spurs extend perpendicularly.

Occurrence.-The species is rare in the Humble Oil and Refining Company's Tindel No. 1 well, Jackson County, Florida, core sample 2,881-2,891 feet, in beds of Eagle Ford age (upper member of Atkinson Formation). It was described from beds of Eutaw (?) and Black Creek (?) age in wells in the Cape Hatteras area, North Carolina and has been recorded from the Upper Cretaceous of Minnesota.

\section{Cythereis sp.}

Plate 3, Figure 10

A few poorly preserved specimens illustrated herein are similar to C. quadrialira (Swain, 1952, p. 84) but the anterior margin is blunter, truncate above and the posterior margin is less pointed than in C. quadrialira; the surface ornamentation is similar to that species.

Length of figured specimen $0.57 \mathrm{~mm}$, height $0.28 \mathrm{~mm}$, convexity $0.23 \mathrm{~mm}$.

Occurrence.-Rare in lower member of Atkinson Formation, Coastal Petroleum Company's No. 1 Wright well, Pinellas County, Florida, core sample 7,100-7,197 feet.

\section{Cythereis fredericksburgoides Swain and Brown, n. sp.}

Plate 3, Figures 9a-f; Text Figure 10a

Shell subquadrate-subacuminate in side view, highest about one-fifth from anterior end; hinge margin somewhat sinuous but fundamentally straight, with strong projection at position of greatest height; both cardinal marginal bends are obtuse, the anterior less broadly so than posterior; ventral margin nearly straight, converging slightly with dorsum in a posterior direction; anterior margin broadly rounded, slightly extend- ed below, subtruncate above, bearing a few short spines; posterior margin subacuminate, strongly extended ventral to midheight, truncate to somewhat concave above, with several short marginal and submarginal spines. Left valve slightly larger than right, extending beyond edge of right anterodorsally and along posterodorsal slope. Terminal parts of valves strongly compressed, ventral surface flattened due to alate expansions; midportion of valves not strongly convex, greatest expansion posteromedian in position.

Anterior marginal area bears a narrow-crested rim from both flanks of which extend five or six narrow perpendicular ridges; marginal rim terminates dorsally in eye tubercle at position of greatest height, and ventrally rim merges with surface at similar position; posterior margin also provided with a narrow low rim along ventral surface of which occur submarginal spines. Along midventral three-fifths of valve is a submarginal rather broad alate ridge that attains greatest height posteriorly and provides flattened wedgeshaped ventral surface of shell; dorsal margin also bears a narrow, low, in part spinose or nodose rim, which extends from a short oblique sulcus in front of eye tubercle to about one-fourth from posterior and where it terminates in a pointed elevation, but also bends ventrally a slight amount. Anteromedially on each valve is a large elongate swelling, posterior to which is a weak broad ridgelike swelling. General surface of valves both coarsely reticulate and finely pitted; in some specimens one or the other predominates.

Hinge of left valve, and anterior rounded deep pit and posteriorly adjacent high curved tooth, an interterminal bar and a posterior slightly oblique deep socket. Inner lamellae moderately wide; line of concrescence and inner margin slightly separated anteriorly.

Length of holotype shell $0.73 \mathrm{~mm}$, height 0.37 $\mathrm{mm}$, convexity $0.36 \mathrm{~mm}$.

Relationships.-Cythereis fredericksburgensis Alexander (1929, p. 89) from the Goodland Limestone of Texas is similar to the present form in shape and main features of surface ornamentation. That species however lacks the terminal ornamentation of the present one and has a more continuous median longitudinal ridge.

Occurrence.-The species occurs in the lower member of Atkinson Formation in the following wells in Florida and Georgia: (1) Sun Oil Company's Westbury No. 1 well, Putnam County, 
Florida, core sample 3,834-3,838 feet; (2) Humble Oil and Refining Company's Tindel No. 1 well, core sample 3,470-3,500 feet; (3) Sun Oil Company's Johnson No. 1 well, Columbia County, Florida, core sample 2,955-2,965 feet; (4) Sun Oil Company's No. 1 Crapps "A" well, Dixie County, Florida, core sample 3,548-3,556 feet; (5) Humble Oil and Refining Company's Bennett and Langdale No. 1 well, Echols County, Georgia, core sample $3,690-3,700$ and $3,700-3,710$ feet.

\section{Cythereis praeornata Swain and Brown, n, name}

Plate 5, Figures 6a-c; Text Figure 10b

Cythere ornata Vanderpool, 1928, Jour. Paleont., v. 2 , p. 106 , pl. 14 , figs. 7,8 .

not Cythere ornata (Bosquet). Bosquet, 1954, Crust. Foss. du Terr. Cret. du Duche de Limbourg, Comm. desc. et geol. carte. Neerlande, Mem., v. 2, p. 102, pl. 9, figs. 8a-d. (fide Howe and Laurencich, 1958).

Shell subquadrate in side view, highest about one-fourth from anterior end ; hinge margin nearly straight, concave medially due to projection of anterior cardinal area; anterior cardinal angle more obtuse than posterior; ventral margin also nearly straight, slightly concave medially and converging slightly with dorsum toward posterior; anterior margin broadly curved, slightly extended below and bears short spines or nodes; posterior margin narrowly curved, extended medially, with four or five short thick spines below and truncate above. Valves subequal, left apparently a little larger than right, and overlapping right along dorsal terminal slopes, although complete cara. pace not seen. Valves relatively strongly compressed, greatest convexity posteromedian.

Anterior margin and adjacent part of ventral margin bear a high rather narrow submarginal rim; dorsally rim terminates in prominent eye tubercle; ventrally, rim passes with slight offset into ventral low alaform ridge that has another narrow low ridge ventral and parallel to it; these two terminate about one-fifth from posterior end, and are connected at their posterior ends by a thick, elevated cross ridge; mid-dorsally is a submarginal ridge that arises a little in front and ventrad of eye tubercle and terminates posteriorly in a thickened and elevated, ventrally pointing spur; a large, strongly elevated anteromedian tubercle slopes gently on its anterior flank and steeply on its posterior side where it is defined by a curving row of five or six pits; posterior to sub- median node is a second smaller node; general valve surface in holotype ornamented by narrow reticulating ridges.

Hinge of right valve consists of an anterior, high, knoblike, somewhat elongate tooth, a posteriorly adjacent triangular socket, an interterminal valve-edge rabbeted above, and a posterior elongated high ridgelike tooth; hinge of left valve has opposite features to those of right valve. Inner lamellae of moderate width, line of concrescence and inner margin mainly coincide but are slightly separated terminally. Radial canals numerous (about 35) closely spaced and tend to occur in pairs anteriorly, less numerous posteriorly. Muscle scar not seen.

Length of holotype left valve (Pl. 5, Fig. 6a) $1.03 \mathrm{~mm}$, height $0.53 \mathrm{~mm}$, convexity of valve 0.27 $\mathrm{mm}$.

Remarks.-This species is close to the general group of Cythereis ornata (Bosquet) (1847, p. 21 ) in shape and surface ornamentation, in fact one wonders whether Vanderpool might not have intended to refer his specimens from Arkansas to Bosquet's species rather than to assume authorship of his Cythereis ornata. Bosquet's ornata, however, is according to Veen (1936, p. 3) (fide Howe and Laurencich, 1958, p. 219) more coarsely reticulate and has a different pattern of ventral ridges than the present form.

Occurrence.-The type specimens are from the DeQueen Limestone Gypsum Bluff, near Murfreesboro, Pike County, Arkansas. According to Vanderpool (1928, p. 107) the species also occurs in the Glen Rose Formation.

Family Cytheruridae G. W. Müller, 1894

Genus Eocytheropteron Alexander, 1933

\section{Eocytheropteron greenvillensis Swain and Brown, n. sp.}

Plate 3, Figures 11a-e; Text Figures 11b, c

Shell, short and high, subpyriform in side view, highest posteromedially; dorsal margin strongly convex, umbonate, anterior slope truncate, posterior slope steep and concave; ventral margin varies from nearly straight or somewhat sinuous in right valve to slightly convex in left valve; anterior margin narrowly rounded, strongly extended below; posterior margin broader, with short, upward pointing caudal process a little above midheight. Left valve larger than right, extending strongly beyond edge of right dorsally and 
Fig. 11
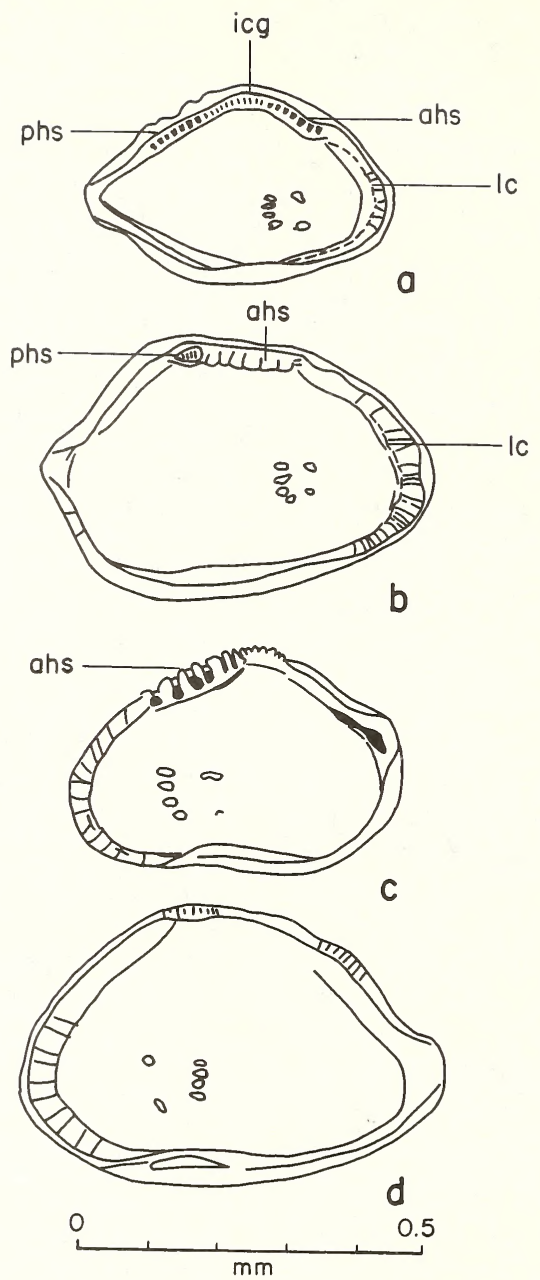
Figure 11.

11a. Eocytheropteron venoides Swain and Brown, n. sp., interior of holotype left valve, beds of Washita age, Greenville City water well, Pitt County, North Carolina, 608-754 feet

11b,c. Eocytheropteron greenvillensis Swain and Brown, n. sp., interior views of paratype left and right valves, beds of Washita age, Greenville City water well, Pitt County, North Carolina, 608-754 feet

11d. Eocytheropteron trinitiensis (Vanderpool), interior of paratype right valve, Glen Rose Formation, eight miles west of Weatherford, Texas 
ventrally, and little or not at all terminally. Valves moderately convex, with greatest tumidity midventral in position. Surface smooth, except for a weak dorsomedian sulcus on right valve.

Hinge of left valve consists of an anterior short pitlike socket that is traversed by one or two low ridges, an interterminal strongly and deeply denticulate taxodont zone, broadest anteriorly and a posterior elongate, finely denticulate shallow socket. Hinge of right valve correspondingly bears an anterior short notched tooth, an interterminal denticulate zone and a posterior crenulate toothlike low elevation.

Muscle scar is composed of a distinctly anteromedian row of four small closely spaced spots plus a curved or double spot lying well in front of upper end of main group. Inner lamellae fairly narrow, broadest anteromedially, where a small vestibule occurs; otherwise line of concrescence and inner margin nearly or entirely coincide. Radial canals few and widely spaced, numbering about six at each end. Anteromidventral margin of each valve bears a prominent selvage apophysis. A low dorsomedian ridge on interior surface of each valve represents position of exterior weak sulcus on right valve, sulcus barely discernible or absent on exterior of left valve.

Length of holotype shell $0.51 \mathrm{~mm}$, height 0.32 $\mathrm{mm}$, convexity $0.22 \mathrm{~mm}$.

Relationships.-This species resembles E. semiconstrictum (Alexander) (1933, p. 198) from the Kiamichi Formation (Albian) of Texas but that species is less umbonate dorsally. E. paenorbiculatum (Alexander) (1933, p. 197) from the Goodland Limestone (Albian) of Texas is strongly umbonate but its caudal process is more ventral in position and is not upturned.

Occurrence.-Early Cretaceous, probably of Albian or upper Aptian age, equivalent to the middle or upper parts of Fredericksburg or lower part of Washita Groups; frequent in Greenville City well, Pitt County, North Carolina, 608-685 feet.

\section{Eocytheropteron venoides Swain and Brown, n. sp.}

Plate 3, Figures 12a-f; Text Figure 11a

Shell of presumed male dimorphs small, shortened-subpyriform in side view, highest medially to anteromedially; dorsal margin strongly convex, angulated at position of greatest height, posteriordorsal slope somewhat truncate; ventral margin moderately convex, slightly sinuous posteromedially; anterior margin narrowly rounded, markedly extended ventral to midheight; posterior margin narrowly curved, with short bluntly pointed, slightly upturned caudal process at midheight. Left valve larger than right, overlapping and extending beyond right along all but posterior margin. Valves strongly convex, greatest tumidity lies posterior to and slightly ventral to middle of shell.

Surface ornamentation varies from nearly smooth to weakly ornamented with narrow closely spaced ridges which are longitudinally arranged and converge backwards in posterior half of shell, and are irregularly arranged anteriorly.

Hinge of left valve composed of an anterior elongate taxodont socket with about five denticles, an interterminal rather short crenulate groove, and a posterior crenulate elongate socket, also with about five denticles. Muscle scar consists of an anteromedian curved row of four spots and an additional horseshoe-shaped spot in front of upper end of main group. Inner lamellae rather narrow, line of concrescence slightly separated from main margin anteriorly. Radial canals few and widely spaced; normal canals not observed. Anteromidventral margin of left valve bears a prominent selvage apophysis which fits over a similar structure of right valve.

Shells of presumed female dimorphs are more elongate and have the caudal process less sharply defined.

Length of holotype shell $0.45 \mathrm{~mm}$, height 0.27 $\mathrm{mm}$, convexity $0.26 \mathrm{~mm}$.

Length of a presumed female left valve 0.55 $\mathrm{mm}$, height $0.30 \mathrm{~mm}$, convexity of valve $0.17 \mathrm{~mm}$.

Relationships. - Eocytheropteron bilobatum (Alexander) $(1929$, p. 104) of the Weno formation (Albian) of Texas is similar to $E$. venoides, n. sp. in shape, overlap relationships of the valves, and character of the caudal process. Alexander's species however, is weakly sulcate dorsomedially, and the surface is finely punctate rather than with venose ridges as in the new species. The dimorphism of the shells of this species is unusual among described representatives of the genus.

Occurrence.-Several specimens of the species were found in the Early Cretaceous, probably of Washita (Albian) age, in the Greenville City well, Pitt County, North Carolina in a composite sample from 608-754 feet. 
Eocytheropteron ef. tumidum Alexander

Plate 3, Figure 13

Cytheropteron tumidum Alexander, 1929, Univ. Texas Bull. 2907, p. 103, pl. 10, figs. 16, 17.

Cytheropteron (Eocytheropteron) tumidum Alexander, 1933, Jour. Paleont., v. 7, p. 199, pl. 27, figs. $13 \mathrm{a}, \mathrm{b}$.

Eocytheropteron tumidum Calahan, 1939, Shreveport Geol. Soc. Guidebook 14th Annual Field Trip, p. 49, pl. 7, fig. 7 .

Howe and Laurencich, 1958, Introd. Study Cretaceous Ostracoda, p. 328, text fig.

Shell almond-shaped in side view, highest anteromedially; dorsal margin moderately convex; ventral margin gently convex; anterior margin rounded, slightly extended below; posterior margin narrower and with compressed, prominently extended, but short, blunt median caudal process. Valves strongly convex, the greatest inflation midventral, where surface overhangs ventral margin. Left valve a little larger than right, overlapping along dorsal and anterior margins.

Ventral portion of each valve bears a narrower sub-alate ridge; between ridge and ventral margin, valve surface flattened but slightly overhangs ventral margin; ventral surface bears low narrow longitudinal ridges between which interspaces are weakly pitted.

Internal characteristics not seen in specimens available for study.

Length of figured specimen $0.58 \mathrm{~mm}$, height $0.36 \mathrm{~mm}$, convexity $0.38 \mathrm{~mm}$.

Remarks.-The general shape and surface ornamentation of this form are closely similar to Eocytheropteron tumidum Alexander, but the preservation of the Florida specimen is poor and the internal features are unknown.

Occurrence.-Lower member of Atkinson Formation, Sun Oil Company's No. 1 Johnson well, Columbia County, Florida, core sample 2,9552,965 feet. The species was described from the Goodland and Kiamichi Formations of Texas and has been recorded from the Lower Cretaceous of northern Louisiana.

\section{Eocy theropteron semiconstrictum Alexander?}

Plate 3, Figures 14a, b

Cytheropteron (Eocytheropteron) semiconstrictum Alexander, 1933, Jour. Paleont., v. 7, p. 198, pl. 26, fig. 8 .
Eocytheropteron semiconstrictum (Alexander). Howe and Laurencich, 1958, Introd. Study Cretaceous Ostracoda, p. 327, text fig.

Shell ovate-pyriform in lateral view, highest anteromedially; dorsal margin strongly convex, sloping nearly uniformly in front of and behind position of greatest height; ventral margin moderately convex, bending more gradually into posterior than into anterior margin; anterior margin broadly rounded, slightly extended below. Valves relatively compressed; greatest convexity ventromedian in position. Left valve slightly larger than and extending beyond edge of right dorsally.

Posterior margin more narrowly rounded, with median blunt caudal process, lateral margins of which produce slight concavities in shell margin. Anteromedially, a shallow subvertical sulcus extends from position of greatest height to midheight. General surface bears a series of weak ridges parallel to anterior and ventral margins and midportion of valves is weakly reticulate. Ventral portion of valve surface formed into longitudinal swellings that slightly overhang ventral margin and produce a flattened venter, in which the valve contact is slightly incised medially.

Internal features of shell not observed.

Length of figured specimen (Pl. 3, Fig. 14a) $0.43 \mathrm{~mm}$, height $0.26 \mathrm{~mm}$, convexity $0.25 \mathrm{~mm}$.

Remarks.-The general shape, convexity, surface ornamentation and median sulcus of this species furnish a comparison with $E$. semiconstrictum Alexander. The dorsal slopes and interior curvature of the posterior margin are slightly different from that described by Alexander, features which may be ascribed to individual variation. The lack of information about internal characteristics prevents more definite identification of the present specimens.

Occurrence.-Lower member of Atkinson Formation, Magnolia Petroleum Company's No. 5B, State Block 1A, Franklin County, Florida, core sample 5,138-5,144 feet. The species was described from the Kiamichi Formation of northeastern Texas.

\section{Eocytheropteron trinitiensis (Vanderpool)}

Plate 5, Figures 4a-e, 5a-c; Text Figure 11d

Cytheridea trinitiensis Vanderpool, 1928, Jour. Paleont., v. 2, p. 106, pl. 14, figs. 3-6. 
Cytheropteron (Eocytheropteron) trinitiensis (Vanderpool). Vanderpool, 1933, Jour. Paleont., v. 7, p. 410, pl. 49, figs. 16-19.

Swain, 1952, U. S. Geol. Survey Prof. Paper 234-B, p. 8C, pl. 9, figs. 9, 10.

Eocytheropteron trinitiensis (Vanderpool). Calahan, 1939, Shreveport Geol. Soc. Guidebook 14th Annual Field Trip.

Eocytheropteron trinitiensis (Vanderpool). Howe and Laurencich, 1958, Introd. Study Cretaceous Ostracoda, p. 327, text fig.

Shell subovate in side view, highest medially; dorsal margin strongly convex, having a slight angulation on posterior slope at posterior end of hinge line; ventral margin moderately convex, curving abruptly into anterior but merging gradually with posterior margin; anterior margin rather narrowly rounded, extended below; posterior margin acuminately extended as a blunt obliquely upturned caudal process, distinctly concave above. Left valve a little larger than right, slightly over-reaching right dorsally and anteriorly; valves strongly convex, the greatest tumidity occurs midventrally. Ventral surface of each valve slightly overhangs margin; along crest of overhanging portion a low ridge occurs. Surface ornamented by irregular, branching, low, narrow, widely spaced ridges that are longitudinally arranged and strongest in ventral half of shell, and are arranged roughly parallel to terminal and dorsal margins in dorsal half of shell.

Hinge of left valve consists of terminal elongate denticulate taxodont sockets and a short, intervening weakly crenulate groove; hinge of right valve correspondingly is formed of terminal elongate, slightly elevated taxodont areas and intervening edge of valve is weakly crenulate to match short groove in left. Inner lamellae of moderate width, line of concrescence and inner margin coincide except ventroterminally, where they are slightly separated. Radial canals few and widely spaced. Muscle scar consists of an anteromedian vertical row of four small spots and two additional spots lying anterior to ends of main group.

Length of holotype shell (Pl. 5, Fig. 4d) 0.74 $\mathrm{mm}$, height $0.48 \mathrm{~mm}$, convexity $0.46 \mathrm{~mm}$.

Remarks.-The specimens from the Paluxy Formation, three miles north of Marietta, Oklahoma have not been seen by the writers and, as suggested by Howe and Laurencich (1958, p. 327), may not be conspecific with trinitiensis because of different surface ornamentation.
Occurrence.-The species was described from the Glen Rose Formation, eight miles west of Weatherford, Texas (Vanderpool, 1928, p. 106), and also occurs in the Glen Rose and DeQueen Formations of Arkansas and northwestern Louisiana and the Trinity (?) and pre-Trinity (?) of the North Carolina subsurface.

\section{Genus Orthonotacythere Alexander, 1933}

\section{Orthonotacythere delicatula Swain and Brown, n. sp.}

Plate 3, Figures 15a-c

Shell subquadrate-acuminate in side view, highest about one-fifth from anterior end ; dorsal margin straight, about three-fourths of shell length, with distinct, moderately obtuse anterior, and more broadly obtuse posterior, cardinal angles; ventral margin straight, subparallel to and about the same length as dorsal margin; anterior margin broadly rounded, somewhat extended below, subtruncate above; posterior margin with compressed bluntly pointed, caudate process extended above midheight. Left valve larger than right, overlapping and overreaching right terminally and dorsally. Valves moderately inflated, greatest convexity posteromedian.

Anterior and posterior marginal zones sharply compressed, free margins provided with narrow thickened low rims. General surface with a prominent dorsomedian high node, and anterodorsal lower node ventrad of small eye tubercle, a posterodorsal node, and a ventral row of four nodes so arranged as to almost form a ridge, the next to posterior node the highest, the two anterior nodes cleatlike. Ventral surface flattened anteriorly, overhangs margin posteriorly and is ornamented with several longitudinal low narrow ridges; median surface of valves densely and finely pitted and with a few weak irregular ridges.

Internal features not seen in the two complete specimens at hand.

Length of holotype shell $0.68 \mathrm{~mm}$, height 0.40 $\mathrm{mm}$, convexity excluding node $0.23 \mathrm{~mm}$, convexity including node $0.40 \mathrm{~mm}$.

Relationships.-The general shape and pattern of ornamenting nodes are similar to $O$. hannai (Israelsky) (1929, p. 12) from the Upper Cretaceous of Arkansas, but that species lacks the sharply acuminate posterior extension of the present form. O. sulcata Brown (1957, p. 23) from the Black Creek Formation of North Carolina is sim- 
ilarly nodose but is more elongate than $O$. delicatula.

Occurrence.-Early Cretaceous, probably of Washita (Albian) age. Caledonia Prison Farm water well T-4, Halifax County, North Carolina, 166-171 feet and 286-291 feet; Odom water well T-1, Northampton County, North Carolina, 190195 feet.

\section{Family Progonocytheridae Sylvester-Bradley, 1948}

Genus Centrocythere Mertens, 1956

Centrocythere annulopapillata Swain and Brown, n. sp.

Plate 3, Figures 16a-c

Shell subpyriform in side view, highest about two-fifths from anterior end, hinge margin nearly straight, about three-fifths of shell length, cardinal angles broadly obtuse, the posterior smaller and more sharply curved than anterior; ventral margin slightly convex, somewhat sinuous due to midventral overhang of margin by shell surface, converging with dorsum posteriorly; anterior margin broadly curved, somewhat extended below, slightly truncate above; posterior margin narrowly rounded, extended medially, truncate above. Left valve slightly larger than right, overlapping and extending beyond right anteriorly and dorsally. Valves moderately convex, greatest convexity midventral in position. Terminal marginal portions of each valve compressed, and margins are finely spinose.

Anterodorsally, valves bear small oblique eye tubercles. Median, ventral, and posterior portions of valve surface ornamented by low, concentrically arranged, papillate ridges; dorsally, similar ridges lie subvertical to margin.

Hinge of right valve consists of an anterior rounded tooth and posteriorly adjacent small socket, an interterminal crenulate groove in hinge margin, and a posterior tooth, details of which are obscured by matrix in available specimen.

Length of holotype (Pl. 3, Fig. 16a) $0.62 \mathrm{~mm}$, height $0.40 \mathrm{~mm}$, convexity $0.36 \mathrm{~mm}$.

Relationships.-The pyriform outline and papillate ornamenting ridges distinguish this species from others described from the Cretaceous. Among other Cretaceous species Cytheropteron sherborni Jones and Hinde is closely similar in shape, papillate concentric ridges, and spinose terminal margins, but was described (Jones and

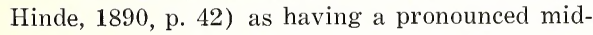

dorsal sulcus that ends in a minute subcentral pit, features which are lacking in the present form.

Occurrence.-Lower member of Atkinson Formation, Sun Oil Company's No. 1 Russell well, Suwannee County, Florida, core sample 3,0703,080 feet; Humble Oil and Refining Company's No. 1 Bennett and Langdale well, Echols County, Georgia, core sample 3,700-3,710 feet; Sun Oil Company's No. 1 Barlow well, Clinch County, Georgia, core sample 3,709-3,711 feet.

\section{References}

Alexander, C. I., 1929, Ostracoda of the Cretaceous of North Texas: Univ. Texas Bull. 2907, 137 p., $10 \mathrm{pls}$.

- 1933, Shell structure of the genus Cytheropteron and species from the Cretaceous of Texas: Jour. Paleont., v. 7, p. 181-214, pls. 25-27.

Applin, P. L. and Applin, E. R., 1947, Regional subsurface stratigraphy, structure and correlation of middle and early Upper Cretaceous rocks in Alabama, Georgia and north Florida: U. S. Geological Survey Oil and Gas Investigations (Preliminary) Chart 26.

Applin, E. R., 1955, A biofacies of Woodbine age in southeastern Gulf Coast region: U. S. Geol. Survey Prof. Paper 264-I, p. 187-197, pls. 48, 49.

Bolin, E. J., 1956, Upper Cretaceous Foraminifera, Ostracoda and Radiolaria from Minnesota: Jour. Paleont., v. 30, p. 279-298, pls. 37-39.

Bosquet, J., 1847, Description des Entomostraces fossiles de la Craie de Maestricht: Soc. Roy. Sci. Liege Mem., v. 4, p. 353-378, pls. 1-4.

Brady, G. S., 1869, On the Crustacean fauna of the salt marshes of Northumberland and Durham: Nat. Hist. Trans. Northumberland and Durham, 1868, v. 3, p. 125.

Brown, P. M., 1957, Upper Cretaceous Ostracoda from North Carolina: North Carolina Dept. Cons. and Devel., Bull. 70,28 p., 7 pls.

1958, Well Logs from the Coastal Plain of North Carolina: North Carolina Dept. Cons. and Devel., Bull. 72, 68 p., 8 pls.

Butler, E. A., and Jones, D. E., 1957, Cretaceous Ostracoda of Prothro and Rayburn Salt Domes, Bienville Parish, Louisiana: Louisiana Geol. Survey, Geol. Bull. 32, 49 p., 6 pls.

Calahan, L. W., 1939, Diagnostic fossils of the Arkansas-Louisiana-Texas area: Shreveport Geol. Soc., Guidebook Fourteenth Ann. Field Trip, p. 36-56, pl. 1-9.

Howe, H. V., and Chambers, J., 1935, Louisiana Jackson Eocene Ostracoda: Louisiana Dept. Cons., Geol. Bull. 5, 65 p., 6 pls. 
Howe, H. V., and Laurencich, L., 1958, Introduction to the Study of Cretaceous Ostracoda: Louisiana State Univ. Press, Baton Rouge, 536 p.

Israelsky, M. C., 1929, Upper Cretaceous Ostracoda of Arkansas: Arkansas Geol. Survey, Bull. 2, 29 p., 4 pls.

Jones, T. R. and Hinde, G. J., 1890, A supplementary monograph of the Cretaceous Entomostraca of England and Ireland: Palaeontographical Soc. London, V. 43, p. i-viii, 1-70, 4 pls.

Lubimova, P. S., 1956, Ostracoda of Cretaceous Formations of the eastern part of the Mongolian National Republic and their importance to stratigraphy: All-Union Petrol. Sci.-Res. Geol. Expl. Inst., Leningrad (VINIGRI), Trans., N. S., No. 93, 174 p., 25 pls., 10 text figs.

Murray, G. E., 1961, Geology of the Atlantic and Gulf Coastal Province of North America: Harper and Brothers, New York, 692 p.

Schmidt, R. A. M., 1948, Ostracoda from the Upper Cretaceous and Lower Eocene of Maryland, Delaware, and Virginia: Jour. Paleont., v. 22, p. 389431, pls. 61-64.
Swain, F. M., 1952, Ostracoda from Wells in North Carolina: Part 2. Mesozoic Ostracoda: U. S. Geol. Survey Prof. Paper 234-B, p. 59-93, pls. 8, 9.

Triebel, E., 1938, Die Ostrakoden der deutschen Kreide. II. Die Cytheridea Arten der Untern Kreide: Senckenbergiana, Bd. 20, t. 471-501, pls. 1-6.

- 1940, Die Ostrakoden der deutschen Kreide. III. Cytherideinae und Cytherinae aus der Unteren Kreide: Senckenbergiana, v. 22, p. 160227, pls. 1-10.

Vanderpool, H. C., 1928, Fossils from the Trinity Group (Lower Comanchean) : Jour. Paleont., v. 2, p. 95-107, pls. 12-14. , 1933, Upper Trinity microfossils from southern Oklahoma: Jour. Paleont., v. 7, p. 406411, pl. 49 .

Veen, J. E. van, 1934, Die Cypridae und Bairdiidae der Maastrichter Tuffkreide und des Kunrader Korallenkalkes von Sud-Limburg: Natuurhist. Maandhl. 24, Jrg., nos. 2-5, p. 26-59, 4 pls. , 1936, Die Cytheridae der Maastrichter Tuffkreide und des Kunrader Korallenkalkes von Sud-Limburg. IV. Die Gattungen Cythereis, Archicythereis und Cytherideis: Natuurhist. Maandhl. 25, Jrg., nos. 11-12, p. 131-168, 9 pls. 


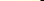




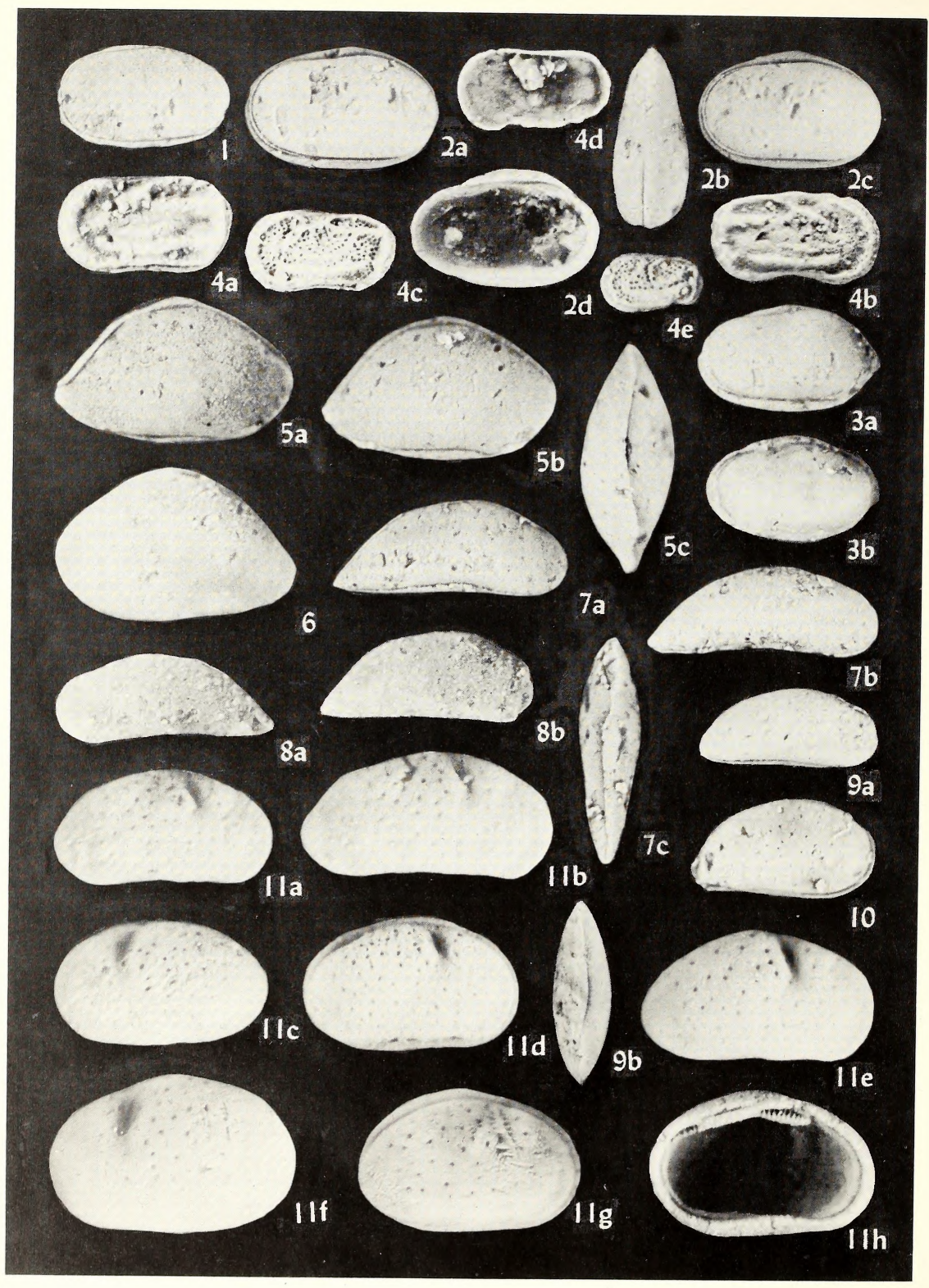


1. Cytherella beyrichoides Swain and Brown, n. sp., lower member of Atkinson Formation, Humble Oil and Refining Company's No. 1 Bennett and Langdale well, 3,700-3,710 feet, x 45 .

Left exterior of holotype shell, U.S.N.M. 132376

2a-d. Cytherella austinensis Alexander, lower member of Atkinson Formation, Humble Oil and Refining Company's No. 1 Bennett and Langdale well, $3,700-3,710$ feet, x 45 .

2a. Left side of shell, U.S.N.M. 132377

2b. Ventral view, U.S.N.M. 132378

2c. Left side of shell, U.S.N.M. 132379

2d. Interior of right valve, U.S.N.M. 132380

3a,b. Cytherella tuberculifera Alexander, upper member of Atkinson Formation, Humble Oil and Refining Company's No. 1 Tindel well, 2,8812,891 feet, $\mathrm{x} 45$.

Left sides of two shells, U.S.N.M. 132381, 132382

4a-e. Cytherelloidea ontovariosa Swain and Brown, n. sp., lower member of Atkinson Formation, Humble Oil and Refining Company's No. 1 Bennett and Langdale well, 3,700-3,710 feet, x 45 .

4a. Left side of holotype shell, U.S.N.M. 132383

4b. Right side of paratype shell, U.S.N.M. 132384

4c. Left side of small paratype, U.S.N.M. 132385

4d. Interior of paratype right valve, U.S.N.M. 132386

4e. Left side of immature paratype, U.S.N.M. 132387

5a-c. Bairdia comanchensis Alexander, lower member of Atkinson Formation, Humble Oil and Refining Company's No. 1 Bennett and Langdale well, 3,700-3,710 feet, x 45 .

5a, b. Right side of two shells, U.S.N.M. 132388, 132389

5c. Dorsal view of 5b, U.S.N.M. 132389

6. Bairdia ? sp., lower member of Atkinson Formation, Humble Oil and Refining Company's No. 1 Cone well, 3,545-3,556 feet, x 45 .

Left side of shell, U.S.N.M. 132390

7a-c. Paracypris goodlandensis Howe and Laurencich, lower member of Atkinson Formation, Humble Oil and Refining Company's No. 1 Bennett and Langdale well, 3,700-3,710 feet, x 45 .

7a, b. Right sides of two shells, U.S.N.M. 132391, 132392

7c. Ventral view, U.S.N.M. 132393

8a,b. Paracypris alta Alexander, lower member of Atkinson Formation, Sun Oil Company's No. 1 Westbury well, 3,834-3,835 feet, x 45 .

8a. Left side of shell, U.S.N.M. 132394

8b. Right side of shell, U.S.N.M. 132395

9a, b. Paracypris sp., lower member of Atkinson Formation, Humble Oil and Refining Company's No. 1 Bennett and Langdale well, 3,700-3,710 feet, $\mathrm{x} 45$.

9a. Right side of shell, U.S.N.M. 132396

9b. Dorsal view, U.S.N.M. 132397

10. Paracyprideis ? graysonensis (Alexander), lower member of Atkinson Formation, Humble Oil and Refining Company's No. 1 Bennett and Langdale well, 3,700-3,710 feet, x 45 .

Right side of shell, U.S.N.M. 132398

11a.-h. Fossocytheridea lenoirensis Swain and Brown, n. gen., n. sp., beds of Washita age, DuPont water well No. 6, Lenoir County, North Carolina, $723-826$ feet, x 43 .

11a. Exterior of immature male paratype right valve, U.S.N.M. 132399

11b. Exterior of male paratype right valve, U.S.N.M. 132400

11c. Exterior of immature female paratype left valve, U.S.N.M. 132401

11d. Right side of holotype female shell, U.S.N.M. 132402

11e. Exterior of paratype female right valve, U.S.N.M. 132403

11f. Exterior of paratype female left valve, U.S.N.M. 132404

11g. Right side of paratype female shell, U.S.N.M. 132405

11h. Interior of paratype female left valve, U.S.N.M. 132406 


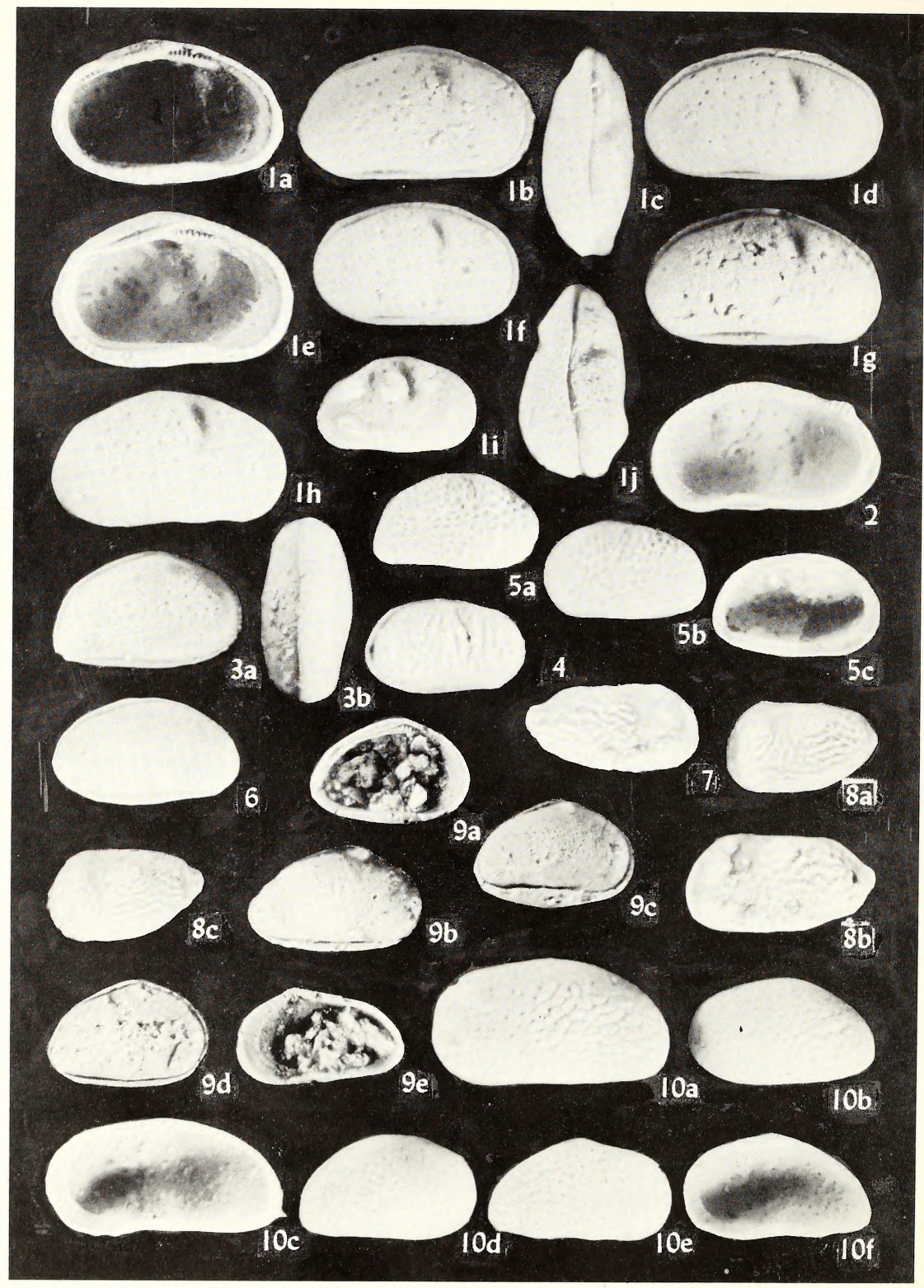


Figures

1a-j,2. Fossocytheridea lenoirensis Swain and Brown, n. gen., n. sp., beds of Washita age, DuPont water well No. 6, Lenoir County, North Carolina, 723-826 feet (1b, 1d, 1e, 1f, 1h, 1i, 2); Odom water well No. T-1, Northampton County, North Carolina, 195-200 feet $(1 \mathrm{c}, 1 \mathrm{j})$; and Greenville City water well, Pitt County, North Carolina, 608-654 feet $1 \mathrm{a}, 1 \mathrm{~g}), \mathrm{x} 43$.

1a. Interior of paratype female left valve, U.S.N.M. 132407

1b. Right side of male paratype, U.S.N.M. 132408

1c. Dorsal view of male paratype, U.S.N.M. 132409

1d. Right side of male paratype, U.S.N.M. 132410

1e. Interior view of female paratype left valve, U.S.N.M. 132411

1f. Right side of immature female paratype, U.S.N.M. 132412

1g. Right side of male paratype, U.S.N.M. 132413

1h. Exterior of female paratype right valve, U.S.N.M. 132414

1i. Exterior of immature nodose right valve, U.S.N.M. 132415

1j. Dorsal view of female paratype, U.S.N.M. 132416

2. Interior of male paratype right valve, U.S.N.M. 132417

3a, b. Haplocytheridea lunarea Swain and Brown, n. sp., upper member Atkinson Formation, Coastal Petroleum Company's No. 1 Larsh well, Jefferson County, Florida, 3,445-3,451 feet, x 45 .

3a. Right side of holotype shell, U.S.N.M. 132418

3b. Dorsal view of paratype shell, U.S.N.M. 132419

4. Haplocytheridea multiclefta Swain and Brown, n. sp., beds of Washita age, DuPont water well No. 6, Lenoir County, North Carolina, 733-743 feet, $\mathrm{x} 45$.

Right side of holotype shell, U.S.N.M. 132420

5a-c. Clithrocytheridea halifaxensis Swain and Brown, n. sp., beds of Washita age, Caledonia Prison Farm water well No. T-4, Halifax County, North Carolina, 151-156 feet (5b) ; and Caledonia Prison Farm water well No. T-2, Halifax County, North Carolina, 166-176 feet (5a), 241-246 feet $(5 \mathrm{c}), \mathrm{x} 45$.

5a. Exterior view of paratype right valve, U.S.N.M. 132421

5b. Exterior of holotype left valve, U.S.N.M. 132422

5c. Interior of paratype left valve, U.S.N.M. 132423

6. Dolocytheridea caledonensis Swain and Brown, n. sp., beds of Washita or Fredericksburg age, Caledonia Prison Farm water well No. T-4, Halifax County, North Carolina, 236-241 feet, x 45.

Right side of holotype shell, U.S.N.M. 132424

7, 8a, b. Perissocytheridea odomensis Swain and Brown, n. sp., beds of Washita age, Caledonia Prison Farm water well No. T-4, 141-146 feet (7), Halifax County, North Carolina; and Odom water well No. T-1, Northampton County, North Carolina, 190-195 feet (8a) and 195-200 feet $(8 \mathrm{~b}), \mathrm{x} 45$.

7. Left side of paratype shell, U.S.N.M. 132425

8a. Exterior of left valve questionably of this species, U.S.N.M. 132426

8b. Left side of holotype shell, U.S.N.M. 132427

9a-e. Schuleridea washitaensis (Alexander), lower member of Atkinson Formation, Humble Oil and Refining Company's No. 1 Bennett and Langdale well, Echols County, Georgia, 3,700-3,710 feet, x 43.

9a. Interior of left valve, U.S.N.M. 132428

9b, c, d. Right sides of three shells, U.S.N.M. 132429, 132430, 132431

9e. Interior of right valve, U.S.N.M. 132432

10a-f. Eucythere semiglypta Swain and Brown, n. sp., beds of Washita age, Caledonia Prison Farm water well No. T-2, 176-181 feet (10e) and 191-196 feet (10a,b,f) Halifax County, North Carolina and No. T-4, 161-166 feet (10c) and 241-246 feet (19d), x 45 .

10a. Exterior of holotype left valve, U.S.N.M. 132438

10b. Exterior of small paratype left valve, U.S.N.M. 132439

10c. Interior of paratype right valve, U.S.N.M. 132440

10d. Right side of paratype shell, U.S.N.M. 132441

10e. Exterior of paratype right valve, U.S.N.M. 132442

10f. Interior of paratype right valve, U.S.N.M. 132443 


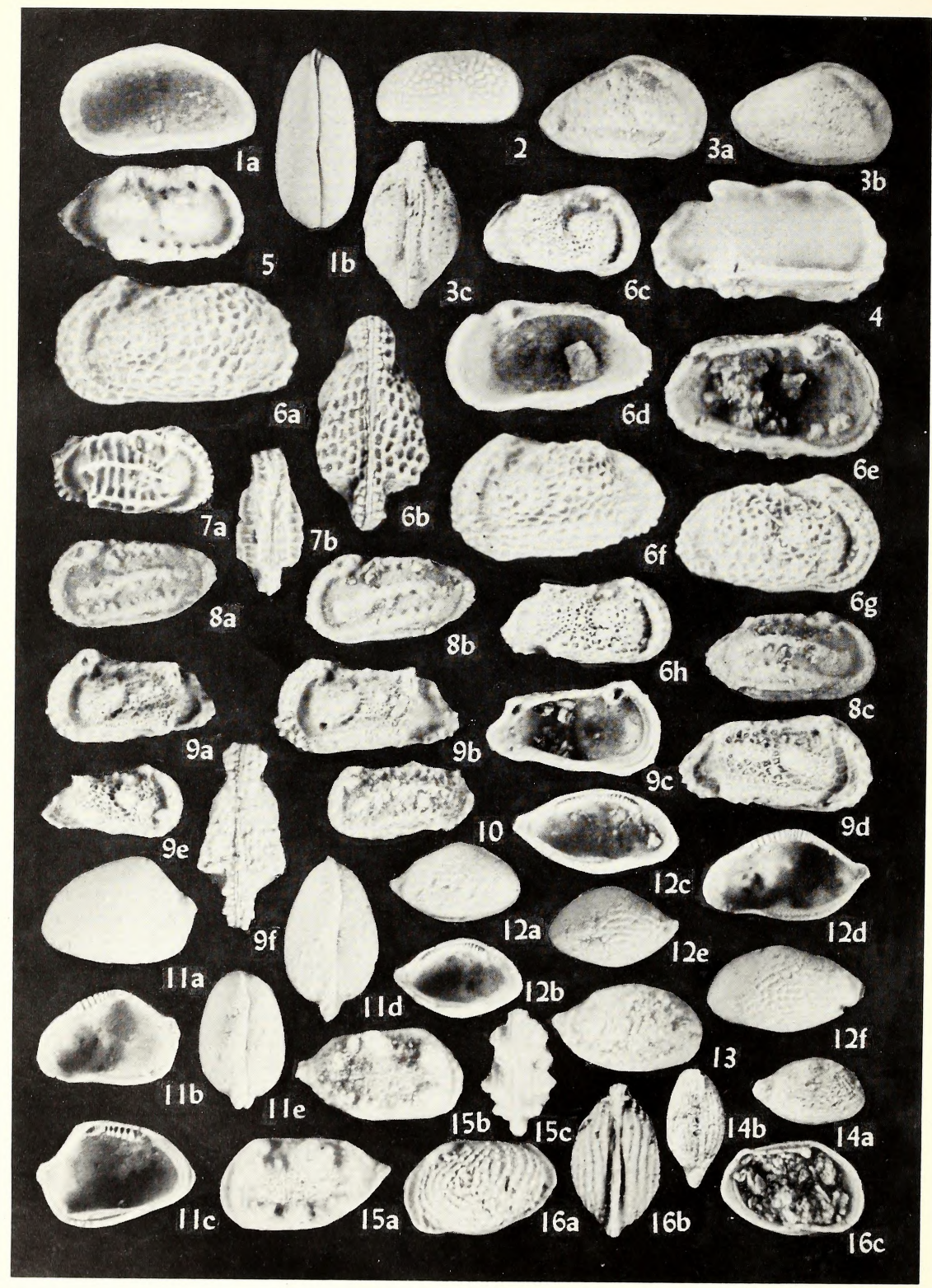


1a,b. Eucythere semiglypta Swain and Brown, n. sp., beds of Washita age, Caledonia Prison Farm water well T-2, Halifax County, North Carolina 191-196 feet (1a), and Odom water well No. T-1, Northampton County, North Carolina 185-190 feet (1b), x 45 .

1a. Interior of paratype right valve, U.S.N.M. 132444

1b. Dorsal view of paratype shell, U.S.N.M. 132445

2. Eucytheroides pustulosa (Swain), beds of Washita age, Odom water well No. T-1, Northampton County, North Carolina, 185-190 feet, x 45.

Exterior of right valve, U.S.N.M. 132446

3a-c. Brachycythere nausiformis Swain, upper member of Atkinson Formation, Escambia Oil Company's State Line Land and Lumber No. 1 well, Escambia County, Alabama, 4,679-4,684 feet, x 43.

3a, b. Right exterior views of two shells, U.S.N.M. 132447, 132448

3c. Ventral view, U.S.N.M. 132449

4. Alatacythere tokiana (Israelsky)?, upper member of Atkinson Formation, Humble Oil and Refining Company's No. 1 Bennett and Langdale well, Echols County, Georgia, 3,700-3,710 feet, x 43 .

Right side of a shell, U.S.N.M. 132450

5. Cythereis sp. aff. C. glabrella Triebel, beds of Washita age, DuPont water well No. 6, Lenoir County, North Carolina, 723-826 feet, x 45.

Exterior of right valve, U.S.N.M. 132451

6a-h. Cythereis eaglefordensis Alexander, lower member of Atkinson Formation, Humble Oil and Refining Company's No. 1 Bennett and Langdale well, Echols County, Georgia, 3,700-3,710 feet, x 43 .

6a. Left side of large female? shell, U.S.N.M. 132452

6b. Ventral view of male shell, U.S.N.M. 132453

6c. Exterior of immature right valve questionably in the species, U.S.N.M. 132454

6d. Interior of right valve, U.S.N.M. 132455

6e. Interior of left valve, U.S.N.M. 132456

6f. Left side of a shell, U.S.N.M. 132457

6g. Right side of a shell, U.S.N.M. 132458

6h. Exterior of an immature right valve, U.S.N.M. 132459

$7 \mathrm{a}, \mathrm{b}$. Cythereis pittensis Swain and Brown, n. sp., Greenville City water well, Pitt County, North Carolina, 608-754 feet, x 45 .

Right side and dorsal views of holotype, U.S.N.M. 132460, 132461

8a-c. Cythereis quadrialira Swain, upper member of Atkinson Formation, Humble Oil and Refining Company's No. 1 Tindel well, Jackson County, Florida, 2,881-2,891 feet, x 43.

8a, b. Left sides of two shells, U.S.N.M. 132462,132463

8c. Right side of a shell, U.S.N.M. 132464

9a-f. Cythereis fredericksburgoides Swain and Brown, n. sp., lower member of Atkinson Formation, Humble Oil and Refining Company's No. 1 Bennett and Langdale well, Echols County, Georgia, 3,700-3,710 feet, $\mathrm{x} 43$.

9a, b. Left sides of two paratype shells, U.S.N.M. 132465, 132466

9c. Interior of a paratype left valve, U.S.N.M. 132467

9d. Right side of holotype shell, U.S.N.M. 132468

9e. Exterior of an immature paratype right valve, U.S.N.M. 132469

9f. Ventral view of a paratype shell, U.S.N.M. 132470

10. Cythereis sp., lower member of Atkinson Formation, Coastal Petroleum Company's No. 1 Wright well, Pinellas County, Florida, 7,100-7,107 feet, x 43, U.S.N.M. 132471

11a-e. Eocytheropteron greenvillensis Swain and Brown, n. sp., beds of Fredericksburg(?) age, Greenville City water well, Pitt County, North Carolina, 608-654 feet, x 45 .

11a. Left side of holotype shell, U.S.N.M. 132475

11b. Interior of paratype right valve, U.S.N.M. 132476

11c. Interior of paratype left valve, U.S.N.M. 132477

11d, e. Dorsal views of two paratype shells, U.S.N.M. 132478, 132479

12a-f. Eocytheropteron venoides Swain and Brown, n. sp., beds of Washita age, Greenville City water well, Pitt County, North Carolina, 608-754 feet, $\mathrm{x} 45$.

12a. Right side of holotype, a male shell, U.S.N.M. 132480

12b. Interior of paratype male left valve, U.S.N.M. 132481

12c. Interior of paratype female left valve, U.S.N.M. 132482

12d. Interior of paratype female right valve, U.S.N.M. 132483 
12e. Left side of male paratype shell, U.S.N.M. 132484

12f. Left side of paratype female shell, U.S.N.M. 132485

13. Eocytheropteron cf. tumidum Alexander, lower member of Atkinson Formation, Sun Oil Company's No. 1 Johnson well, Columbia County, Florida, 2,955-2,965 feet, $\mathrm{x} 45$.

Left side of shell, U.S.N.M. 132486

14a, b. Eocytheropteron semiconstrictum ? Alexander, lower member of Atkinson Formation, Magnolia Petroleum Company's No. 5B State Block 1A well, Franklin County, Florida, 5,138-5,144 feet, x 43 .

14a. Right side of a shell, U.S.N.M. 132495

14b. Ventral view, U.S.N.M. 132532

15a-c. Orthonotacythere delicatula Swain and Brown, n. sp., beds of Washita age, Odom water well No. T-1, Northampton County, North Carolina, 190-195 feet (15a) ; Caledonia Prison Farm water well No. T-4, Halifax County, North Carolina, 166-171 feet (15b) and 286-291 feet $(15 \mathrm{c}), \mathrm{x} 45$.

15a. Left side of holotype shell, U.S.N.M. 132496

15b. Right side of paratype shell, U.S.N.M. 132497

15c. Dorsal view of paratype, U.S.N.M. 132498

16a-c. Centrocythere annulopapillata Swain and Brown, n. sp., lower member of Atkinson Formation, Humble Oil and Refining Company's No. 1 Bennett and Langdale well, Echols County, Georgia, 3,700-3,710 feet, $\mathrm{x} 43$.

16a. Left side of holotype shell, U.S.N.M. 132499

16b. Ventral view of paratype, U.S.N.M. 132500

16c. Interior of paratype left valve, U.S.N.M. 132501 



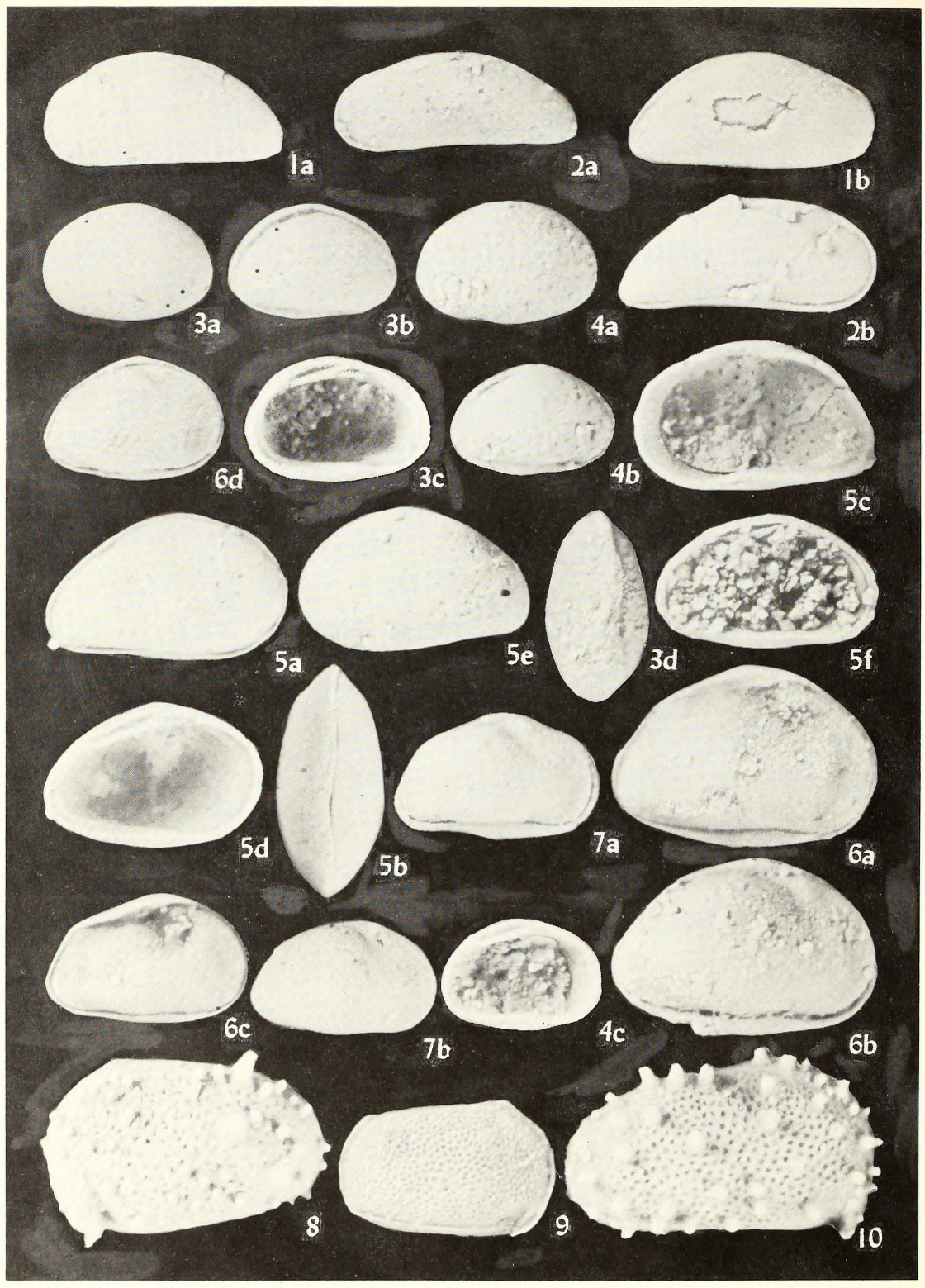


1a,b. Paracypris wcatherfordensis Vanderpool, Glen Rose Formation, west of Weatherford, Texas, x 52 .

1a. Exterior of paratype left valve, U.S.N.M. 132502

1b. Right side of holotyp 3 shell, U.S.N.M. 132503

2a,b. Paracypris c. P. angusta Alexander, Glen Rose Formation, west of Weatherford Texas, x 52 .

2a. Left side of a shell, U.S.N.M. 132504

2b. Right side of a shell, U.S.N.M. 132505

3a-d. Asciocythere rotunda (Vanderpool), Glen Rose Formation, west of Weatherford, Texas, x 52 .

3a. Exterior of a paratype left valve, U.S.N.M. 132506

3b. Right side of paratype shell, U.S.N.M. 132507

3c. Interior of holotype left valve, U.S.N.M. 132508

3d. Dorsal view of a paratype shell, U.S.N.M. 132509

4a-c. Asciocythere rotunda (Vanderpool), Glen Rose Formation, west of Weatherford, Texas, x 52 .

4a. Left side of a paratype shell, U.S.N.M. 132510

4b. Right side of a paratype shell, U.S.N.M. 132511

4c. Interior of paratype left valve, U.S.N.M. 132512

5a-f. Asciocythere perforata (Vanderpool), Glen Rose Formation, west of Weatherford, Texas, x 52 .

5a. Right side of holotype shell, U.S.N.M. 132513

5b. Dorsal view of paratype, U.S.N.M. 132514

5c. Interior of paratype right valve, U.S.N.M. 132515

5d. Interior of paratype left valve, U.S.N.M. 132516

5e. Exterior of paratype left valve, U.S.N.M. 132517

5f. Interior of paratype left valve, U.S.N.M. 132518

6a-c. Schuleridea dorsoventrus (Vanderpool), $(=$ the holotype of "Bairdia glenrosensis" Vanderpool), Glen Rose Formation, west of Weatherford, Texas, x 52 .

6a. Right side of holotype shell, U.S.N.M. 132433

6b. Right side of paratype shell, U.S.N.M. 132434

6c. Right side of small paratype shell, U.S.N.M. 132435

7a,b. Schuleridea dorsoventrus (Vanderpool), Glen Rose Formation, west of Weatherford, Texas, x 52 .

7a. Right side of a paratype shell, U.S.N.M. 132436

7b. Exterior of a paratype right valve, U.S.N.M. 132437

8. Cypridea dequeenensis Swain and Brown, n. sp., DeQueen Limestone at Gypsum Bluff, Pike County, Arkansas, x 52 .

Exterior of holotype left valve, U.S.N.M. 132519

9. Cypridea diminuta Vanderpool, DeQueen Limestone at Gypsum Bluff, Pike County, Arkansas, x 52 .

Right side of holotype, U.S.N.M. 132523

10. Cypridea wyomingensis Jones, DeQueen Limestone at Gypsum Bluff, Pike County, Arkansas, x 52.

Exterior of holotype right valve, U.S.N.M. 132528 


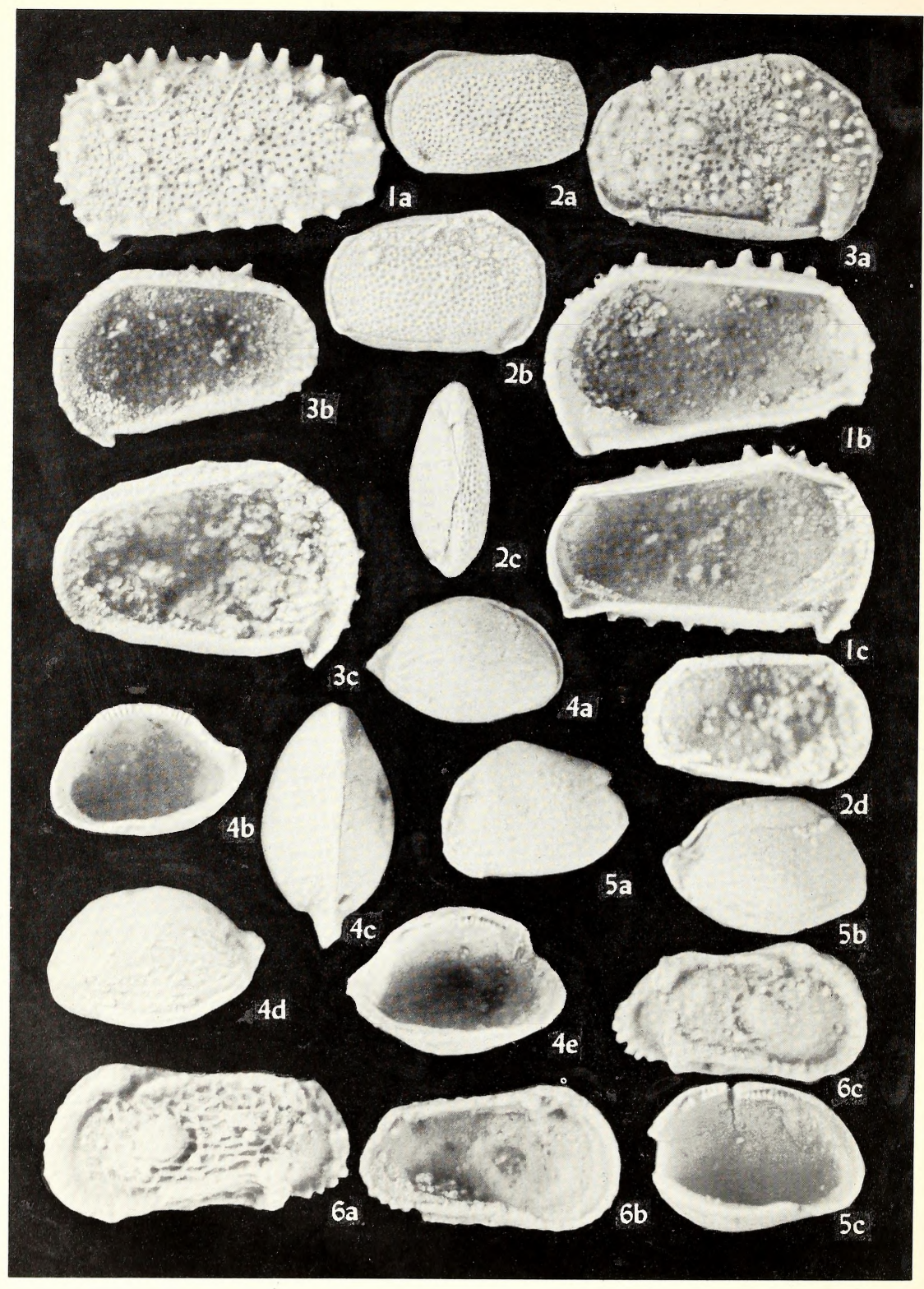




\section{Plate 5}

Figures

(re-illustration of Vanderpool's types)

1a-c. Cypridea wyomingensis Jones, DeQueen Limestone at Gypsum Bluff, Pike County, Arkansas, x 52.

1a. Exterior of paratype right valve, U.S.N.M. 132529

1b. Interior of paratype right valve, U.S.N.M. 132530

1c. Interior of paratype left valve, U.S.N.M. 132531

2a-d. Cypridea diminuta Vanderpool, DeQueen Limestone at Gypsum Bluff, Pike County, Arkansas, x 52.

2a. Left side of a paratype shell, U.S.N.M. 132524

2b. Right side of a paratype shell, U.S.N.M. 132525

2c. Ventral view of a paratype shell, U.S.N.M. 132526

2d. Interior of a paratype left valve, U.S.N.M. 132527

3a-c. Cypridea dequeenensis Swain and Brown, n. sp., DeQueen Limestone at Gypsum Bluff, Pike County, Arkansas, x 52 .

3a. Right side of a paratype shell, U.S.N.M. 132520

3b. Interior of a paratype right valve, U.S.N.M. 132521

3c. Interior of a paratype left valve, U.S.N.M. 132522

4a-e. Eocytheropteron trinitiensis (Vanderpool), DeQueen Limestone at Gypsum Bluff, Pike County, Arkansas, x 52 .

4a. Right side of a paratype shell, U.S.N.M. 132487

4b. Interior of paratype right valve, U.S.N.M. 132488

4c. Dorsal view of paratype shell, U.S.N.M. 132489

4d. Left side of holotype shell, U.S.N.M. 132490

4e. Interior view of a broken paratype left valve, U.S.N.M. 132491

5a-c. Eocytheropteron trinitiensis (Vanderpool), x 52.

5a. Left side of broken paratype shell, U.S.N.M. 132492

5b. Right side of a paratype shell, U.S.N.M. 132493

5c. Interior view of a broken left valve paratype, U.S.N.M. 132494

6a-c. Cythereis praeornata Swain and Brown, n. name, DeQueen Limestone at Gypsum Bluff, Pike County, Arkansas, x 52.

6a. Exterior of holotype left valve, U.S.N.M. 132472

6b. Interior of paratype left valve, U.S.N.M. 132473

6c. Exterior of paratype right valve, U.S.N.M. 132474 



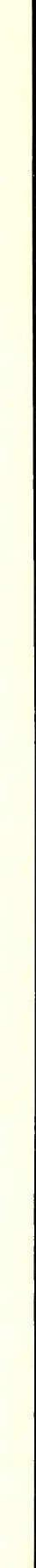




